UNIVERSIDADE DE SÃO PAULO

INSTITUTO DE RELAÇÕES INTERNACIONAIS

Leonardo J. E. Falabella

Who Gets the Anti-Establishment Vote? CRisis, Elections, and Populism in Western Europe 
LEONARDO J. E. FALABELLA

\section{Who Gets the Anti-Establishment Vote? Crisis, Elections, and Populism in Western Europe}

Dissertação apresentada ao Programa de Pós-Graduação em Relações Internacionais do Instituto de Relações Internacionais da Universidade de São Paulo, para a obtenção do título de Mestre em Ciências.

Orientador: Prof. Dr. Pedro Feliú Ribeiro 
Autorizo a reprodução e divulgação total ou parcial deste trabalho, por qualquer meio convencional ou eletrônico, para fins de estudo e pesquisa, desde que citada a fonte.

Catalogação da Publicação

Instituto de Relações Internacionais da Universidade de São Paulo

Falabella, Leonardo

Who Gets the Anti-Establishment Vote? Crisis, Elections, and Populism in Western Europe / Leonardo Falabella - Orientador: Pedro Feliú Ribeiro. São Paulo: 2017.

$45 \mathrm{p}$.

Dissertação (Mestrado) - Instituto de Relações Internacionais. Universidade de São Paulo.

1. Processo político. 2. Partidos políticos - Europa. 3. Polarização. I. Ribeiro, Pedro Feliú. II. Título. 
Aos contribuintes do Estado de São Paulo, financiadores da maior e mais importante universidade latino-americana.

Aos contribuintes brasileiros em geral, financiadores da Capes e da Universidade Federal de Minas Gerais, provedora das bases da minha formação.

A Pedro Feliú Ribeiro, o melhor orientador que se poderia ter. A Fernando Limongi e Janina Onuki, que se juntam ao Pedro por terem viabilizado o meu próximo passo.

A Glauco Peres da Silva e Natália Dus Poiatti, pelas observações na banca de qualificação. A Matheus Soldi Hardt, pela terna amizade e pelas contribuições incomensuráveis a esta pesquisa.

Por fim, o agradecimento mais importante: aos meus pais, pelo amor incondicional. 
Acendo a televisão

Vejo o Passos Coelho a dizer que em breve saímos da recessão Porque é que a gente vota nesses políticos? São extensões do poder econômico, tá mais que explícito

Assaltam o estado, dão cargos aos aliados Das autarquias aos ministérios, tá tudo manietado Privatizam a justiça em nome deles Instrumentalizam os media para nos deixarem alienados

É a falência da democracia representativa Que apenas pariu corrupção e uma massa passiva Uma massa inofensiva de homens que se subjugaram Que abdicaram do país que eles usurparam e desmantelaram Trecho de "No Meu Quarto", do rapper português Valete $\rrbracket^{1}$

\footnotetext{
${ }^{1}$ Valete. No meu quarto. Valete. 2012. MP3.
} 


\begin{abstract}
Why does the extreme right grow in some parts of Europe while the radical left rises in others? In studies about both party groups, the hypothesis that economic distress provides them with opportunity is frequently tested. Yet, little effort has been employed in comparing their performances under different economic conditions. This article fills this gap through panel data analysis, with disaggregated data from eight countries in election years between 2002 and 2011. It finds that voting for extreme right parties increases significantly after the financial crisis outbreak of 2008, with no corresponding evidence for radical left parties. Also, extreme right support has a positive link to regional GDP per capita and a negative link to unemployment rates. In contrast, radical left parties perform better where unemployment is higher. The results suggest that economic downturns are mostly beneficial to extreme right parties, but this effect is increasingly neutralized in regions of high unemployment.
\end{abstract}

Keywords: Electoral Success, Radical left, Extreme Right, Polarization, Populism

\title{
Resumo
}

Por que a extrema direita cresce em alguns países europeus, ao passo que a esquerda radical cresce em outros? Em estudos sobre ambas as categorias de partido, testa-se frequentemente a hipótese segundo a qual eles têm janelas de oportunidade em crises. Ainda assim, pouco esforço vem sendo feito para comparar como eles se saem sob diferentes contextos econômicos. Este artigo preenche tal lacuna através de análise de dados em painel, com dados desagregados de oito países, em eleições entre 2002 e 2011. O artigo aponta que a votação da extrema direita aumenta significativamente com o desenrolar da crise de 2008, ao passo que não se encontram evidências correspondentes para a esquerda radical. Ademais, o apoio eleitoral à extrema direita é positivamente ligado a ínidices regionais de PIB per capita, e negativamente ligado a taxas de desemprego. Por contraste, partidos de esquerda radical se saem melhores onde o desemprego é alto. Os resultados sugerem que quedas na atividade econômica são majoritariamente benéficas à extrema direta, mas que tal efeito é crescentemente neutralizado em regiões de alto desemprego.

Keywords: Sucesso eleitoral, esquerda radical, extrema direita, polarização, populismo 


\section{Contents}

\begin{tabular}{lll}
\hline & Introduction & 6
\end{tabular}

\begin{tabular}{|lll}
2 & European populism in context & 9
\end{tabular}

3 Polarization and Economics 13

3.1 Right-wing Populism: Is it the Economy? . . . . . . . . . . . . . . . . . 15

$\begin{array}{lll}4 & \text { Data and Methods } & 17\end{array}$

4.1 Data and Sources . . . . . . . . . . . . . . . . . . . . 17

4.2 Methodology $\ldots \ldots \ldots \ldots \ldots \ldots$

4.3 Models . . . . . . . . . . . . . . . . . . . . . . . . . . . . . . . . . . . . . 20

\begin{tabular}{ll|l}
5 & Results & 23
\end{tabular}

\begin{tabular}{lll}
\hline 6 & Discussion & 27
\end{tabular}

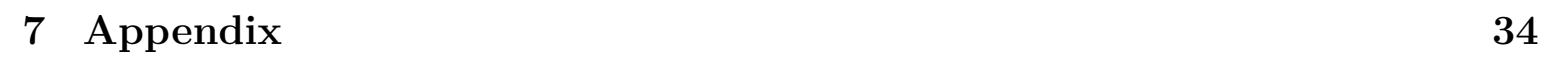




\section{Introduction}

Anti-political establishment parties (APEs), left and right, are on the rise in Western Europe $2^{2}$ in some countries, they have become active players, thus earning greater attention ${ }^{3}$. Existing evidence links economic anxiety to political polarization ${ }^{4}$ but little is known on why different countries have the vector of radicalism pointing to opposing ends.

This puzzle motivates the present article, which compares economic conditions that associate with voting for radical left parties (RLPs) and extreme right parties (ERPs). I test corresponding models for each party group - with subnational data from seventeen contests in eight countries - to examine if economic growth, unemployment, and income per capita are linked to vote shares for radical parties. In this way, I clarify the link between economic anxiety and political polarization, therefore supporting future analyses that shall approach this issue from different angles.

Rising populism 5 is not exclusive to Europe, as it also occurs across the Atlantic. Neither is it novel to frame populist upsurge from an economic standpoint. For example, Rodrik (2017) addresses the broader context of populist backlash by stressing the role of economic globalization. As he argues, globalization sets the stage for populism because specific groups suffer with exposure to trade openness, financial liberalization, and growing capital mobility. Indeed, multiple studies show that APEs thrive where employment is hurt by foreign trade ${ }^{6}$ though evidence is weaker for the roles of financial liberalization and capital mobility.

Economic shocks are considered demand-side factors - in accordance with the sup-

\footnotetext{
${ }^{2}$ Eleven out of fourteen European countries had radical parties with vote shares above ten percent in parliamentary elections held until June 2016 (see Figure 1 on page 11).

${ }^{3}$ Examples of recent studies directed at APEs include March and Rommerskirchen (2015), Dennison and Pardijs (2016), Rodrik (2017), Guiso, Herrera, and Morelli (2017), and Colantone and Stanig (2016), to name but a few.

${ }^{4}$ See Section 3 on page 13 .

${ }^{5}$ For remarks on the terms "anti-establishment", "populism", "radicalism", and "extremism", see page 9 .

${ }^{6}$ See Subsection 3.1 on page 15 .
} 
ply and demand conceptual framework developed for radical parties (as in Mudde, 2007; March and Rommerskirchen, 2015 Burni, 2017). Accordingly, the demand side consists of economic and cultural backgrounds - social settings that provide insurgent parties with windows of opportunity, potentially leading more voters to comply with radicalism. On the other hand, the supply side involves external competition, institutional factors, and party leadership (March and Rommerskirchen, 2015, p. 41).

In Rodrik's approach, the demand side for a populist surge has dislocated citizens growing angry with the political establishment, thus becoming potential supporters of anti-system platforms. On the supply side, populist actors seek to resonate with their base by framing specific groups as being guilty of economic disarray. The targets will differ for each variant of populism: While populists on the right point to minorities and out-groups (immigrants, roma, foreign competitors), left-wing populists blame corporations and economic elites (Rodrik, 2017, p. 25).

To the best of my knowledge, no more than two attempts have been made at explaining the determinants of success for each variant of populism, one of them from Rodrik himself: Where disaffected voters are surrounded by immigrants, the cleavage emphasized by right-wing populists becomes more salient. As a result, it gets easier to channel economic anxiety into hostility to migrants. This would be the case of European countries where the extreme right is on the rise. Conversely, where the shocks of globalization can be traced to financial crises and foreign interference in domestic affairs, the cleavage emphasized by left-wing populists comes to the surface, prompting mobilization against economic elites. That would the case of Latin America and, similarly, the European countries where left-wing populism is successful, such as Greece, Spain, and Portugal (Rodrik, 2017, p. 4).

The parallel between southern Europe and Latin America is also present in a second answer, elaborated by Philippe Schmitter $7^{7}$. Borrowing from Italian-Argentine sociolo-

\footnotetext{
${ }^{7}$ Elaborated during an interview for Mundo 2017, podcast) - transcript on page 45
} 
gist Gino Germani, Schmitter uses the concept of status incongruence $\rrbracket^{8}$ to hypothesize that populists gain support from people whose self-image of societal status is not reflected in reality. An example of the incongruous, in this sense of the word, is a group with accomplishments that are not recognized by the ruling elite. This would be the case of Argentine peronistas and, similarly, voters of radical left parties in southern Europe. In contrast, a second example of an incongruous group is a middle class facing economic decline - a "downward" rather than "upward" incongruity. In the Northern European case, the downward incongruous would be precisely the workers threatened by globalization and de-industrialization.

Noticeably, the two propositions are not mutually exclusive, as they could be simultaneously at play. My data does not allow to determine which explanation is the most pertinent. It does, however, allow us to examine the link between economic anxiety and anti-establishment vote in further detail, therefore extending what we know. For example, before laying out his account, Rodrik states that economic shocks produce opportunities for populism, but do not determine its political orientation. While I forcefully agree, my results show that different indicators of economic anxiety correlate with support for different variants of populism. These findings, coupled with additional existing evidence, shall help to set the tone for a more nuanced understanding of anti-establishment vote.

I proceed by addressing some idiosyncrasies of the European case, such as the continent's radical parties, the political economy of European Union membership, and its ongoing crisis. Still in the following section, I draw an overview of recent performances by APEs in parliamentary elections. Subsequently, I examine the existing literature on economic anxiety and political polarization, before exposing my data, methodology, and results. I conclude by examining how the results relate to existing hypotheses on the rise of different variants of populism.

\footnotetext{
${ }^{8}$ As in Germani, Tella, and Ianni 1977 , p. 42).
} 


\section{European populism in context}

Before contextualizing European populism, it is important to address issues of conceptual clarity. I depart from the definition of populism as a rhetoric emphasizing the cleavage between masses and elites $\bigsqcup^{9}$ As such, it can be employed by both left-wing and right-wing actors. Especially in the current European context, anti-establishment discourse is a common feature of populist parties (Dennison and Pardijs, 2016, Rodrik, 2017), in a way that the two terms can be used interchangeably without a loss of precision. Finally, I follow the bulk of the literature by employing the term radical for populist left-wing parties and extreme for populist right-wing parties.

Extreme right and radical left parties alike have undergone renewal in the last decades. Transformation in extreme right parties occurred from the 1980s onward: unlike their predecessors, contemporary ERPs do not advocate for dictatorial orders, being supportive of republican principles and democratic institutions (Minkenberg, 2013). Instead, the renewed far right focuses on identity politics, claiming to stand against a political elite that allegedly betrays the population by allowing the inflow of migrants and therefore threatening national identities (Mudde, 2010).

In parallel, radical left parties faced renewal during the aftermath of 1989, by no longer presenting themselves as the vanguard of the proletariat. By the last decade, March and Mudde (2005) spoke of "decline and mutation" among the radical left, in that mutation was meant by RLPs presenting themselves as the "voice of the people" against organized interests of ruling financial elites. This reflects a move away from advocating soviet-like socialism, assimilating what is now considered an important trait of the radical left: a distrust in non-elected bureaucracies and ensuing defense of electoral accountability (ibid; March, 2008)

\footnotetext{
${ }^{9}$ For more on this account of the term, see Panizza $(2005)$, Derks $(2006)$, and Tella $(2010)$.

${ }^{10}$ Interestingly, already in 1988, Herbert Kitschelt stressed this feature in a paper on left-libertarian parties: "left-libertarians oppose the centralized bureaucratic welfare state and the hegemony of professional expertise in public policy and society. In their view, the formal rationalities of markets and bureaucracies expropriate the citizen's capacity to determine their own lives and must be checked by institutions that impose substantive standards of rationality on their boundless expansive dynamic." Kitschelt (1988, p. 197).
} 
Resulting from concurrent transitions, radical left and extreme right have come to share a common trait in their populistic tones. Considering the end of the cold war with integrating markets, capital mobility, and financial globalization, it is reasonable to suppose that shifts have occurred as means of adaptation to societal change, with parties compelled to shift their attention to cleavages that became more salient due to economic globalization.

The European case includes yet a particular trait that speaks directly to this adjustment: According to Mair (2013, p. 129), the advancement of European integration generated a profound representative crisis, owing to the bureaucratized, nondemocratic nature of the European Union's political system. To Mair, EU politics is non-democratic due to its lack democratic accountability, with its decision-makers rarely mandated by voters. Consequently, EU politics leaves little scope for opposition within its own system, engendering anti-political sentiment across electorates.

Challenging the political establishment, then, becomes an opportune strategy as bureaucratization feeds into popular frustration, which should occur especially when policy areas that get transferred from ballots to technocrats are precisely the ones that unnerve radical parties. While radical left parties contest the imposition of austerity measures by non-elected technocrats, right-wing populists emphasize national identities in opposition to integration and resent losing national autonomy over border controls.

If radical parties could find an opportune scenario with the EU bureaucratized political system, the more so when the continent faces a widespread economic crisis. For Müller (2014), the European crisis strengthens radical parties by aggravating anti-political sentiment. Accordingly, voters would tolerate the democratic deficit so long as elites were trusted and people's daily lives were not affected. With the erosion of this tacit agreement, disapproval of traditional politicians ensues, bringing about growing polarization. 
Figure 1: Anti-political establishment party (APE) vote shares in recent elections

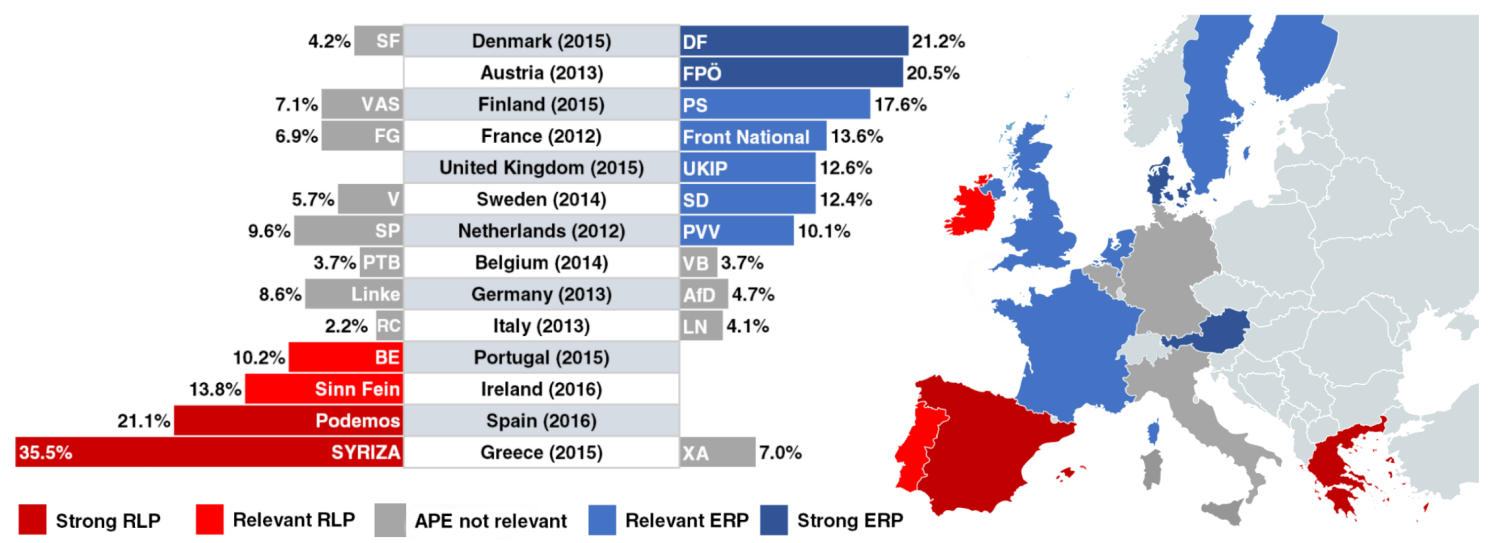

Figure 1 shows the performances of APEs in 14 Western EU member: 11 in the most recent parliamentary election until June 2016. I classify parties into five categories of APE performance: where a party surpasses ten percent of the vote, I assign it as relevant, and parties above the twenty percent mark are considered strong ${ }^{12}$.

The resulting map reveals a blatant geographical cleavage: extreme right parties thrive mostly in northern countries, whereas the majority of successful radical left parties (RLPs) are in the south. But what else can be said about the "leftist" south as opposed to the "right-wing" north? In order to contrast these countries, I lay out the different categories of APE success against five indicators, as seen in Figure $2 \|^{3}$.

The data disclose additional cleavages. Firstly, RLPs perform well in countries where government consumption expenditure shrank the most. Voters in Ireland, Greece, Portugal, and Spain saw the outrage of radical left parties as their countries received financial assistance under the imposition of austerity measures. Interestingly, budget cuts are the only indicator at which Ireland, the sole northern country with a relevant

\footnotetext{
${ }^{11}$ This includes the United Kingdom, still a member in 2015.

${ }^{12}$ At any country, a party with more than ten percent of the vote places itself on the top quartile of the distribution among parties. I take this as a sign of relevance. Further, a party with a vote share above twenty percent will be above the 5th percentile in any country, which I take as a sign of strength.

${ }^{13}$ Sources: World Development Indicators (WDI) and European Values Study (EVS); Indicators are collected at the election year for contests that take place during the second semester. For elections held in the first semester, a one-year lag applies. As in Minkenberg (2013), a person is classified as "xenophobic" when he/she responds to the question, "Could you please sort out any that you would not like to have as neighbors?," by mentioning at least one of the following categories: "Muslims," "Immigrants," and "People of a different race."
} 
RLP, stands next to its southern counterparts.

Figure 2: Economic conditions and radical party vote, 2011-16

Horizontal dotted lines represent average European Union levels
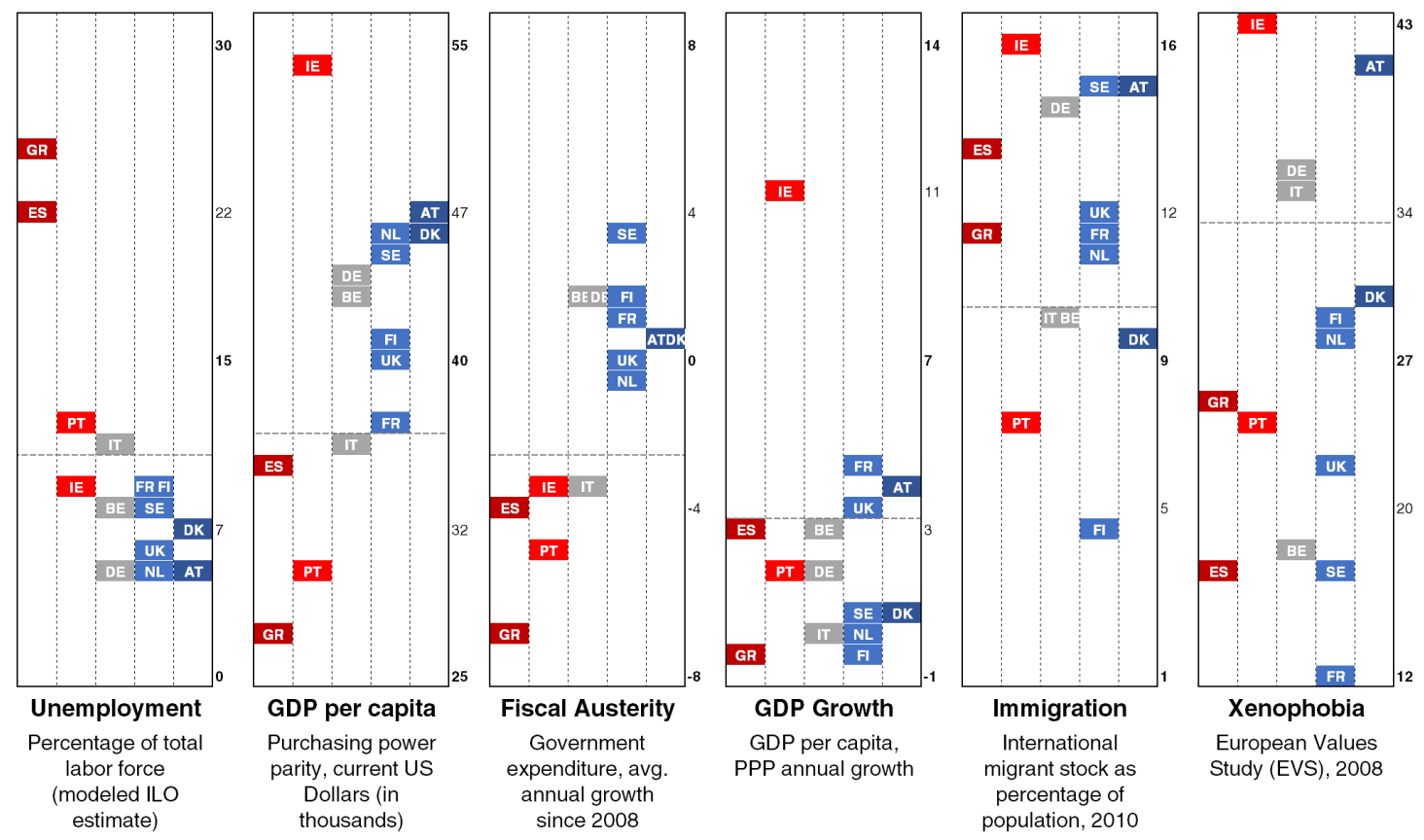

Greece, Portugal, and Spain, in turn, form a cohort with not only considerable budget cuts but also lower GDP per capita and high unemployment rates. As for levels of unemployment, the two countries with the highest figures (Greece and Spain) also show the greatest support for the radical left. Portugal lags behind next to Italy, the exemplary counterfactual case, lacking a relevant RLP albeit moving along with its neighbors at every economic indicator, from budget cuts to unemployment to GDP per capita.

Moving onto extreme right support, we can see that "blue" countries, in general, have above-average GDP, lower unemployment rates, and virtually no sign of fiscal austerity measures, with the Netherlands as the sole case of an overall decrease in government expenditure. Denmark and Austria, the two countries where ERPs perform the best, are seen cut off from most of their neighbors as nations with especially high levels of GDP per capita. Overall, countries where the extreme right shows strength display comparatively favorable economic indicators. 
Contrary to some expectations (e.g. Golder, 2003 Lubbers, Gijsberts, and Scheepers, $2002)$, migration levels do not separate left from right-leaning electorates, neither do aggregate levels of xenophobic attitudes. Both countries with low (Portugal, Finland) and high levels of migrants (Spain, Ireland, Germany, Sweden, Austria) have electoral results ranging across the board. Similarly, no cleavage can be detected by looking at the extent to which citizens discriminate against minorities, for diverse electoral results take place both among countries with low (Spain, Sweden, France) and high rates (Ireland, Austria, Germany).

We have seen that three out of four countries with relevant radical felt parties share high levels on unemployment, below-average GDP per capita, and draconian austerity measures. The latter indicator also applies to Ireland, the sole left-leaning country outside of southern Europe. North of the continent, where most right-leaning countries are located, high GDP per capita and low unemployment rates stand out as distinctive features. Neither economic growth rates nor indicators of ethnic diversity appear as distinguishing variables.

This country-level descriptive analysis allowed including variables that are not available in subnational data. However, as we move on to panel data analysis, we aggregate more observations and greater variability. Because I focus on economic variables, I proceed to review the literature on economic anxiety and political polarization.

\section{Polarization and Economics}

One could expect the literature on economic voting as the frame of reference for a study on economic issues and populist party vote. Yet, there are limits to how it can contribute to research on anti-political establishment parties (APEs). Knowingly, the economic voting theory proposes that voters will support the government in times of prosperity and withdraw support in times of hardship (Lewis-Beck and Nadeau, 2011). Focusing on government-opposition dichotomy differs economic voting theory 
from analyses that look at specific, unorthodox party groups that may or may not be in government coalitions. In any case, we should consider a study by Lewis-Beck and Nadeau (2012). After examining debt-burdened European countries (Portugal, Italy, Greece, and Spain), they conclude that economic voting has greater weight in these electorates than anywhere else in Europe. An implication could be that radical left parties tend to profit when socioeconomic issues gain salience. But then again, this finding does not address far-left parties directly, meaning that one should look elsewhere for a solid background on anti-establishment parties.

Few studies analyze APE performance through a comparative take on far-left and far-right parties, with results suggesting that economic distress is more conducive to populism on the right. For example, using electoral data from developed countries, Funke, Schularick, and Trebesch $(2015)$ indicate that financial crises increase extreme right party (ERP) support, with little evidence of impact for the radical left. Similarly, analyzing aggregate survey data from OECD countries, Brückner and Grüner (2010) find a negative effect of GDP per capita growth on support for the far-right, while results for communist parties are inconclusive. Finally, Burni (2017) employs individual-level data to show that extreme-right voters tend to be less satisfied with the economy than supporters of the radical left. Taken together, these results could lead one to discard a connection between RLP performance and economic anxiety.

However, research on European radical left parties (RLPs) directly contradicts this picture. Studies on France (Sperber, 2010), Germany (Bowyer and Vail, 2011), and a cross-country comparison by March and Rommerskirchen (2015) have coinciding results, all stressing high unemployment rates, poor economic conditions, and a broad sense of economic insecurity as boosters of RLP support. In particular, Bowyer and Vail (2011, pp. 701-702) also show that German supporters of Die Linke are more likely to come from disadvantaged groups. Yet, when addressing macroeconomic conditions, they ponder that the relationship between economic distress and far-left appeal may not be monotonic, and could pertain to specific circumstances. 
The literature on radical left parties is in unison some central issues, perhaps owing to its limited scope. Only a few studies focus on RLP performance, with most analyses concerned with their organization and behavior (E.g. Bartolini, 2007; Hudson, 2012, Bale and Dunphy, 2011). This can be a reflection of how radical left parties have only recently begun to rise (March and Mudde, 2005, March, 2008, March and Rommerskirchen, 2015), after remaining sluggish for most of the 1990s and 2000s. In contrast, studies on ERP support date from way before (E.g. Beyme, 1988, Husbands, 1991; Jackman and Volpert, 1996; Knigge, 1998), which reflects on a wider range of methods, samples, and claims. Jointly, it is a more controversial field, overall deserving of a somewhat lengthy, detailed exposition. I do so by focusing on the issue that directly concerns this work.

\subsection{Right-wing Populism: Is it the Economy?}

In addition to evidence from comparative studies on anti-establishment parties, research on globalization shocks highlight the role of trade exposure in explaining farright success (Swank and Betz, 2003; Dippel, Gold, and Heblich, 2015; Autor et al., 2016; Colantone and Stanig, 2017; Guiso, Herrera, and Morelli, 2017). Additionally, Becker, Fetzer, and Novy (2016) and Colantone and Stanig (2016) show a correlation between exposure to import competition and "Leave" voting on the Brexit referendum. These analyses make the case for framing right-wing populism as a reaction from workers threatened by international trade: In Rodrik's words, "even when the underlying shock is fundamentally economic the political manifestations can be cultural and nativist. What may look like a racist or xenophobic backlash may have its roots in economic anxieties and dislocations" (Rodrik, 2017, p. 24).

Yet, the emphasis on economic insecurity is rebuffed by important experts on rightwing populism 14 . For instance, Cas Mudde (2007, p. 230) claims that even by demonstrating that globalization shocks feed into nativist backlash, cross-country differences

\footnotetext{
${ }^{14}$ In particular, Cas Mudde appears to be especially emphatic about this contention, to the point of his 2007 book including a chapter entitled "It's not the economy, stupid!"
} 
would remain unexplained - since globalization shocks are present across Europe, and ERPs are not successful everywhere. The same reasoning would apply to levels of political resentment and xenophobia, also seen as pan-European phenomena. While acknowledging contextual factors as creators of fertile grounds, Mudde asserts that populist right parties, like any other, mobilize only a fraction of their potential electorates. Therefore, the existence of such fertile grounds are deemed a necessary, but not sufficient condition for ERP rise.

Also, not only do ERPs fail to attract the totality of "globalization losers", as they also have cross-class, heterogeneous electorates that comprise the wealthy (Müller, 2016. Evans, 2005; Ivarsflaten, 2005; Zhirkov, 2014). Indeed, studies looking at aggregate levels of wealth and employment have diverging results, with the majority showing that ERPs are more successful where unemployment is lower, and income, higher ${ }^{15}$. Finally, an individual-level study by De Weerdt et al. (2004) shows that, on average, economic insecurity tends to mitigate extreme right party affinity, while the opposite applies to people in comfortable situations. Regarding this evidence, Müller 2016, p. 14) reasons that well-off citizens often display Social Darwinist attitudes toward the disfavored. Others (Mudde, 2007; Lubbers, Gijsberts, and Scheepers, 2002) hypothesize that wealthier citizens may be afraid of losing their economic advantage when confronted with perceived threats of globalization, including mass immigration.

But even regarding immigration, results from empirical research are contradictory. While some studies associate extreme right support with higher contingents of migrants (Golder, 2003, Lubbers, Gijsberts, and Scheepers, 2002), others find no correlation at all (Wendt, 2003. Norris, 2005; Mudde, 2007). Further, despite the evidence that individual xenophobic attitudes translate into ERP support, additional research indicates that this relationship does not carry over to national aggregate levels (Norris, 2005; Mudde, 2007). Indeed, descriptive data shown in Figure 2 endorse a lack of

\footnotetext{
${ }^{15}$ To best of my knowledge, only Jackman and Volpert (1996) associate ERP vote shares with higher unemployment, whereas the inverse is found by Lubbers, Gijsberts, and Scheepers (2002) and Knigge (1998). Additionally, Coffé, Heyndels, and Vermeir (2007) indicate that wealthier Belgian districts tend to be more reliable supporters of the Vlams Blok.
} 
relationship on the national level, both in terms of international migrant stocks and of aggregate levels of xenophobic attitudes. All in all, previous studies on ethnic diversity and socioeconomic conditions seem to contradict the portrait of right-wing backlash as resulting from globalization losers' resentment.

In light of conflicting data, how should we grasp the evidence that far-right parties succeed where growth rates are lower and trade exposure is greater? The answer possibly lies in the heterogeneity of ERP electorates. Or at least one could reasonably expect that as a rejoinder from authors like Cas Mudde and Jan-Werner Müller, who label the "losers of globalization thesis" as simplistic and insufficient. Arguably, trade shocks translate into far-right support via impact on one of the subgroups that integrate ERP voter bases. If this assumption holds true, trade shocks, even if significant, would still leave a substantial part of the puzzle unaddressed.

Regarding the present work, a possible implication can be that it provides an incomplete picture, given that, in Mudde's terms, fertile grounds are a "necessary, but not sufficient condition". However, considering the effort of integrating radical left and extreme right support into the analysis, the importance of comparison becomes clear. In this sense, Mudde's claim could be rephrased to state that economic conditions are "not sufficient, but necessary". Therefore, understanding who has the edge when faced with certain economic climates is the first step to solving a pressing puzzle. It is to that effort that I now turn.

\section{Data and Methods}

\subsection{Data and Sources}

This work runs regressions for two dependent variables: the vote shares of extreme right parties (ERPs) and radical left parties (RLPs) in nineteen parliamentary elections. The sample contains electoral and economic data from elections in eight countries, 
held between 2002 and 2011 $1^{16}$. By disaggregating data by 138 subnational regions ${ }^{17}$ the sample gains extensive variability - not only in economic variables but also in vote shares for radical parties (page 34 in the Appendix).

To classify parties as belonging to the extreme right or radical left, I turn to the Chapel Hill Expert Survey (CHES). The CHES attributes numeral scale scores to parties' positions in four different dimensions, also listing parties into families according to experts' answers. By selecting the parties that the survey counts as "Radical Right" and "Radical Left", the sample computes eight ERPs and eight RLPs. This output is endorsed by different sources on European party families 18 .

Table 1: Countries, Anti-Political Establishment Parties (APEs), and Election Years

\begin{tabular}{llll}
\hline Country & Extreme Right & Radical Left & Election Years \\
\hline Austria & FPÖ, BZÖ & - & $2002,2006,2008$ \\
Belgium & VB & WPB & $2003,2007,2010$ \\
Denmark & DF & SF & 2007 \\
France & FN & PCF & 2002 \\
Germany & NPD & Linke & 2005 \\
Greece & LAOS & SYRIZA, KKE & $2004,2007,2009$ \\
Netherlands & PVV & SP & $2002,2003,2006,2010$ \\
Spain & - & IU & $2004,2008,2011$ \\
\hline
\end{tabular}

Noticeably, the time-span omits the emergence of recent insurgent parties, such as Podemos in Spain and Alternative für Deutschland (AfD) in Germany. It also fails to grasp the skyrocketing performances by SYRIZA from 2012 onward. Yet, testing for associations during over a decade - comprising contests before and after the 2008 crisis outbreak - should provide relevant insights to understanding APE support in contrasting backgrounds. Allied with national aggregate data, regression estimates from this period can illustrate a large piece of the puzzle.

\footnotetext{
${ }^{16}$ Independent variables correspond to the election year if a contest is held during the second semester, and lagged otherwise.

${ }^{17}$ Regional division by the European Union's geocode standard: Nomenclature of Territorial Units for Statistics (NUTS). Data are disaggregated by NUTS 2 regions, roughly correspondent to states. Electoral results provided by the European Election Database (EED); socioeconomic variables by Eurostat.

${ }^{18}$ For an account from different sources, see page 35
} 


\subsection{Methodology}

Because ERPs and RLPs are not present in every country, the bulk of the literature refrains from using ordinary least squares regressions. Running OLS models with missing values where a radical party is absent would exclude countries with economic conditions that discourage the anti-establishment vote, leading to biased and inconsistent estimates (Golder, 2003 Jesuit, Paradowski, and Mahler, 2009). In turn, by employing OLS while coding these observations as zero, one would assume that regressors and dependent variables have no correlation (March and Rommerskirchen 2015). Consequently, several studies 5 use the Tobit estimator, which employs a maximumlikelihood estimator for left-censored variables and therefore accommodates the limited nature of the dependent variable. In the Tobit model, the coefficients represent the marginal effects of the regressors on the vote shares of radical left and extreme right parties.

The Tobit estimator has the problem of assuming normal and homoscedastic distribution of the error term. When a misspecification occurs, Tobit estimates are inconsistent and inefficient (Wooldridge, 2010, p. 533). In dealing with this problem, I include country dummies and compute Huber-White robust standard error 20 Further, I run supplementary regressions after transforming dependent variables with the inverse hyperbolic sine (IHS), which approximates a logarithm ${ }^{21}$. The IHS transformation ameliorates heteroscedasticity and the non-normality of the error term by reducing the variability of dependent variables ${ }^{22}$. Results of IHS regressions were partially similar to conventional ones (see page 37 in the Appendix).

\footnotetext{
${ }^{19}$ E.g. Jackman and Volpert (1996), Golder (2003), Jesuit, Paradowski, and Mahler (2009), Coffé, Heyndels, and Vermeir (2007), and March and Rommerskirchen (2015).

${ }^{20}$ As in Golder (2003 country dummies only) and Jesuit, Paradowski, and Mahler (2009, both strategies).

${ }^{21} \sin ^{-1} y=\ln \left(y+\sqrt{1+y^{2}}\right) \approx \ln 2+\ln y$

${ }^{22}$ As in Jesuit, Paradowski, and Mahler (2009).
} 


\subsection{Models}

Two separate dependent variables - vote shares for radical left and extreme right parties - are tested in two models, totaling four regressions. Most independent variables reflect this work's focus on economic conditions. Yet, dummy variables control for the permissiveness of electoral systems and ideologies of incumbent coalitions, since neglecting them could lead to biased results (Golder, 2003 March and Rommerskirchen, 2015).

Model 1:

$R L P V O T E(E R P V O T E)=$

$$
\begin{aligned}
& \beta_{0}+\beta_{1} G D P+\beta_{2} U N E M P+\beta_{3} G R O W T H \\
& +\beta_{4} \text { THRESH }+\beta_{5} C O N S I N G O V(S O C I N G O V) \\
& \quad+\beta_{\mathrm{n}} \text { CountryDummies }+\epsilon
\end{aligned}
$$

\section{Model 2:}

$$
\begin{aligned}
& R L P V O T E(E R P V O T E)= \\
& \qquad \beta_{0}+\beta_{1} G D P+\beta_{2} U N E M P+\beta_{3} C R I S I S \\
& +\beta_{4} C R I S I S * G D P+\beta_{5} C R I S I S * U N E M P \\
& +\beta_{6} \text { THRESH }+\beta_{7} C O N S I N G O V(S O C I N G O V) \\
& +\beta_{\mathrm{n}} \text { CountryDummies }+\epsilon
\end{aligned}
$$

It is reasonable to expect an inverse association between GDP per capita and RLP vote, given the evidence of better performance under poor economic conditions (E.g. March and Rommerskirchen, 2015; Bowyer and Vail, 2011) and in less developed countries (Bartolini, 2007). Conversely, evidence for "prosperity-born bitterness" (as discussed in Mudde, 2007; Lubbers, Gijsberts, and Scheepers, 2002) and from regionallevel analysis by Coffé, Heyndels, and Vermeir (2007) suggest a positive link between 
regional income levels and extreme right support:

Hypothesis 1: RLPs are more successful in regions with lower GDP per capita.

Hypothesis 2: ERPs are more successful in regions with higher GDP per capita.

As noted in Section 3, most analyses suggest that unemployment rates (UNEMP) have a positive link to radical left support, whereas the inverse applies to extreme right parties:

Hypothesis 3: RLPs are more successful in regions with higher unemployment.

Hypothesis 4: ERPs are more successful in regions with lower unemployment.

As noted by Brückner and Grüner (2010), GDP per capita growth (GROWTH) describes an economic shock, making it different from variables depicting ex-ante levels of wealth and employment. Studies on economic shocks and radical parties suggest that the far-right fares better in crisis contexts, with little evidence on the left (ibid, Funke, Schularick, and Trebesch, 2015). Even still, aforementioned studies on RLPs make a strong case for expecting a negative link to growth. Therefore:

Hypothesis 5: The lower the annual growth rate in a region, the higher the support for an RLP.

Hypothesis 6: The lower the annual growth rate in a region, the higher the support for an ERP.

Model 2 substitutes GROWTH for CRISIS - a dummy that takes the value 1 for elections held after September 2008 ${ }^{23}$. Model 2 also includes two interaction terms involving the crisis dummy (CRISIS*GDP and CRISIS*UNEMP). Lewis-Beck and Nadeau (2012) state that economic issues have greater weight in elections during downturns:

Hypothesis 7: RLP support was greater between September 2008 and 2011.

Hypothesis 8: ERP support was greater between September 2008 and 2011.

Hypothesis 9: Relationships between economic indicators and anti-establishment

\footnotetext{
${ }^{23}$ Correlation coefficient for GROWTH and CRISIS is -0.78 (see page 40 .
} 
party (APE) vote, when existent, became stronger after September 2008.

Dummy variables in the models control for external institutions and actors that can affect the performance of anti-political establishment parties. Specifically, they pertain to the ideologies of governing coalitions and the openness of institutions to political parties.

CONSINGOV and SOCINGOV control for incumbency: the former for center-right, conservative/Christian-democratic parties, and the latter for traditional social-democratic parties. They are tested alternately on the dependent variables: CONSINGOV against RLPVOTE; SOCINGOV against ERPVOTE. The radical left is found to perform better when the executive is held by a right-wing party (March and Rommerskirchen, 2015, p. 48), indicating that RLPs can excel as repositories of anti-right protest. Besides this hypothesis, I test if an equivalent process occurs with the extreme right:

Hypothesis 10: RLP support is higher when the executive is held by a right-wing party.

Hypothesis 11: ERP support is higher when the executive is held by a left-wing party.

As indicators of the openness of political institutions, one could attempt to thresholds of representation and/or proportionality of electoral systems (Lijphart and Aitkin, 1994, pp. 25-56). Because the vast majority of European systems are PR ${ }^{24}$ I focus on thresholds. THRESH is a dummy variable that takes the value 1 where a party must obtain at least 3 percent of the votes to take one seat in the legislature ${ }^{25}$

Hypothesis 12: RLP support is lower in less permissive electoral systems.

Hypothesis 13: ERP support is lower in less permissive electoral systems.

Finally, country dummies are used in the face of heteroscedasticity (Golder, 2003 Jesuit, Paradowski, and Mahler, 2009), and to take account of potential country het-

\footnotetext{
${ }^{24}$ For a detailed account of the electoral systems in the sample, see page 42

${ }^{25}$ The value 3 percent is chosen as it approximates the mean threshold in the sample $(3.19 \%)$.
} 
erogeneity (N. Beck, 2001). No hypothesis are drawn, and their results are not of interest in this study.

\section{Results}

Figure 3: Dependent Variables are the Vote Shares for Extreme Right and Radical Left Parties

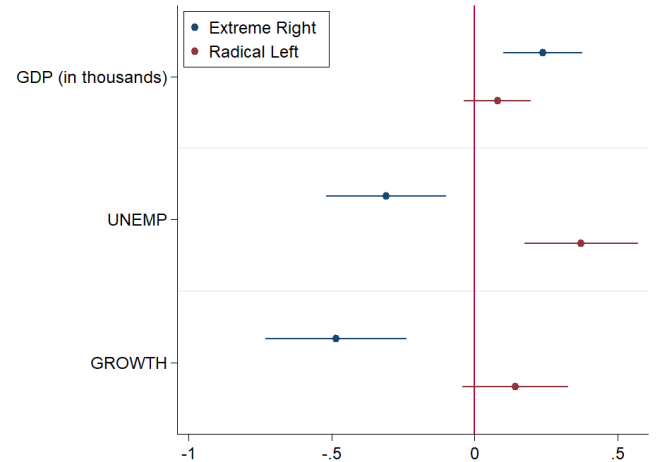

(a) Model 1 - Continuous Variables

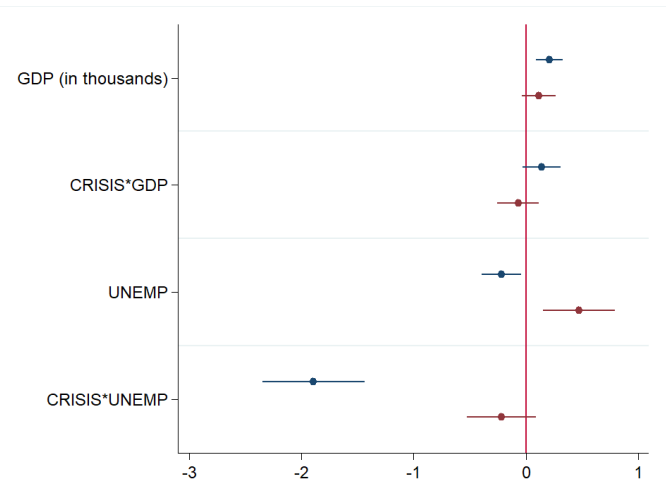

(c) Model 2 - Continuous and Interactions

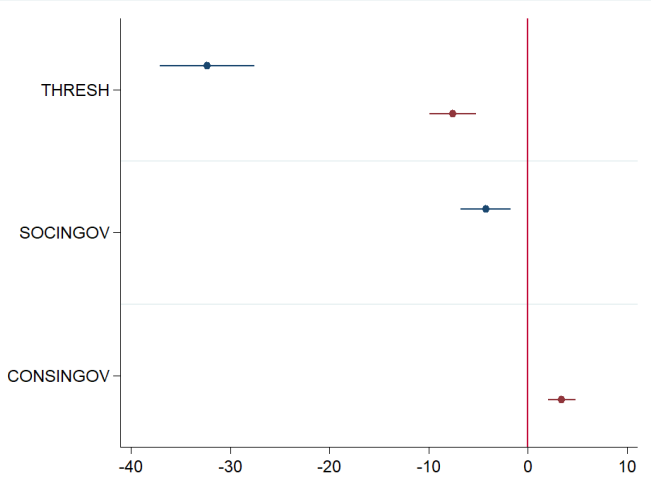

(b) Model 1 - Dummy Variables

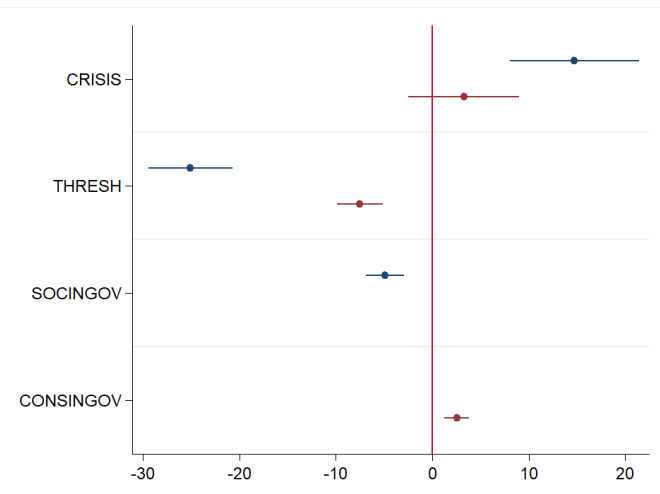

(d) Model 2 - Dummy variables

Results are presented graphically in Figure [l] $^{6}$, with Figures $3 \mathrm{a}$ 3b representing Model 1; 3c/3d reflecting Model 2. For better visualization, plots are broken down into continuous variables and interaction terms on the left-hand side $3 \mathrm{a}, 3 \mathrm{c}$ ); and dummy variables on the right-hand side $(3 \mathrm{~b}, 3 \mathrm{~d})$. Discussion below focuses on Model 2.

Already at first glance, models for extreme right parties (ERPs) display more signif${ }^{26}$ Detailed estimates in the Appendix (page 36 . 
icant estimates. They reveal an average increase of 14.75 percentage points in vote shares after 2008 (H8), and a negative correlation with growth rates (H6). Additionally, ERPs have greater appeal in wealthier regions (H2), and where unemployment is lower (H4). Also, estimates reveal that the negative link between unemployment and extreme right support is much stronger for elections held after the financial crisis outbreak (partially H9).

Conversely, radical left party (RLP) vote and unemployment show a positive link (H3). Figure 4a depicts the predictive margins of unemployment rates on RLP support, vertical lines representing mean (solid line) and bounds of standard deviation (dashed lines) of UNEMP. Noticeably, a one percent increase from mean unemployment of 8.8 percent is expected to result in additional 4 percentage points in RLP support ${ }^{27}$

On the other hand, neither GDP per capita nor growth rates display significant estimates, and far-left parties' votes do not increase after 2008 (H1-5-7). This sets an apparent contradiction, which is clarified by additional data. Box plots in Figure 4b contrast unemployment levels in years before and after 2008: Average unemployment rates rose from approximately 8.2 to 10.7 percentage points, with standard deviations of 4.9 and 7.7, respectively (see page 34 in the Appendix). These data signal that the post-2008 rise of unemployment was not meaningful to the point of implying a boost for the radical left.

The behavior of unemployment before and after 2008 also matters to understand extreme right support. Model 2 presents a significant, but remote coefficient at -0.22 for UNEMP in the pre-2008 period, contrasting with a slope of -2.15 for post-2008 years. Figure 5 compares the predictive margins of unemployment before and after the financial crisis outbreak: In post-2008 years, a decrease in one percentage point from 8.5 percent of unemployment should reflect a rise of $2 \mathrm{pp}$ in ERP vote shares. Inversely, a rise from 11 to 12 percent of unemployment should imply a loss of 2.6

\footnotetext{
${ }^{27}$ However, these results are not cross-validated by inverse hyperbolic sine (IHS) regressions, thus weakening estimates' robustness. I consider the implications of this robustness check in the discussion section (page 27).
} 
Figure 4: Unemployment and Radical Left Support
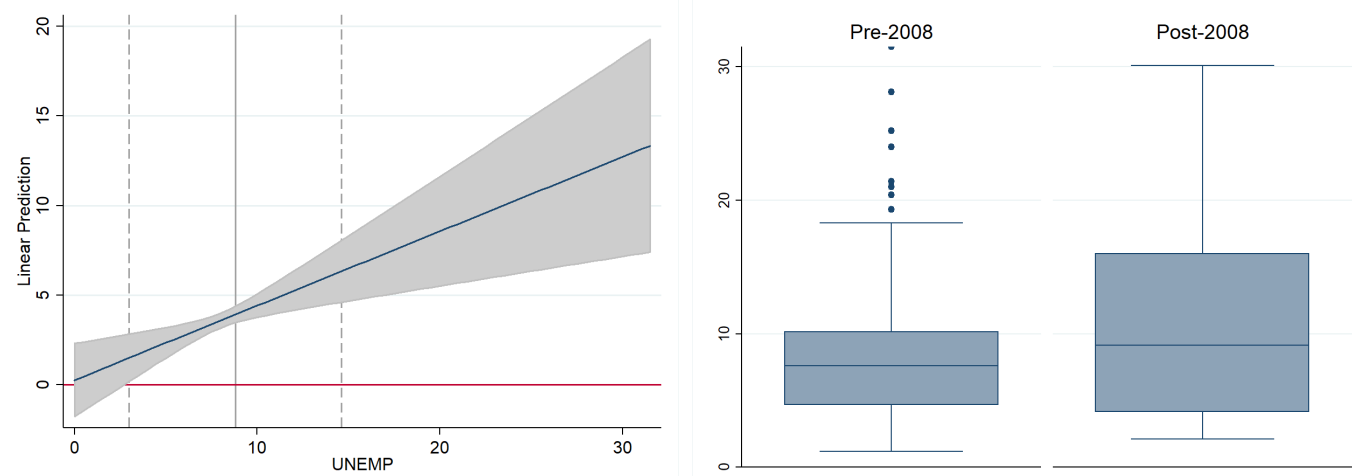

(a) Predictive Margins of UNEMP on (b) Unemployment levels before and after RLPVOTE with 95\% CIs - Model 22008

points. Contrasted with the estimate for CRISIS, this suggests that the post-2008 rise in ERP support was increasingly neutralized in high unemployment regions. In this sense, a poor job market may have been an "antidote" against right-wing backlash.

Further avowing the existence of "prosperity-born bitterness", ERP support has a positive link with income per capita, its estimate suggesting that additional 10 thousand Dollars in income imply an additional 2.4 pp in ERP support. The coefficient looks minor, but it could help explain important variance, given the sample with GDPs above 40 thousand as well as below 20 thousand Dollars. For instance, data from 2003 reveal a gap of nearly 37 thousand Dollars between the Belgian provinces of Brussels and Hainaut. Coincidentally or not, that particular contest had the extreme right-wing Vlaams Blok attaining over $9 \%$ of the vote in Brussels, and a mere $0.85 \%$ in Hainaut. This further illustrates the validity of disaggregated data, for such a disparity would not be grasped by country-level analysis.

Moving onto external institutions and political actors, electoral thresholds and incumbent parties alike display significant estimates. Anti-establishment parties (APEs) perform much worse if electoral thresholds are above 3 percent (H12-13), especially regarding the far-right. ERPs are expected to receive 25 percentage points less in this circumstance, while a corresponding estimate of -7.5 applies to the radical left. Moreover, RLPs receive additional $2.5 \mathrm{pp}$ of votes when the executive is held by a right-wing 
Figure 5: Predictive Margins of Unemployment on Extreme Right Party Vote Share, Before and After 2008 (Model 2); 95\% Confidence Intervals

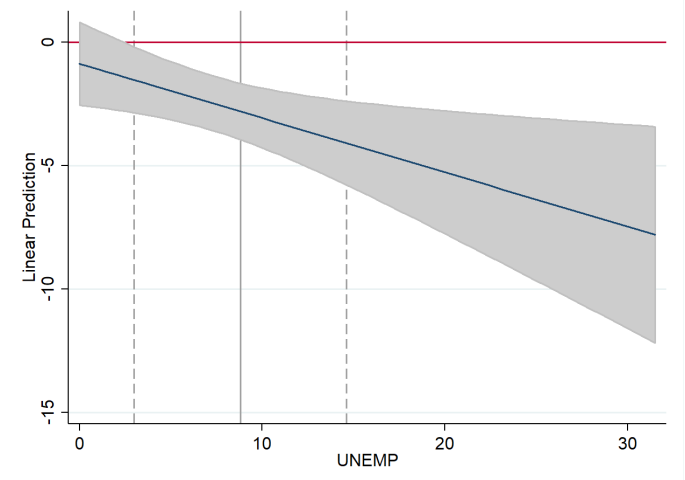

(a) Pre-2008 (CRISIS=0)

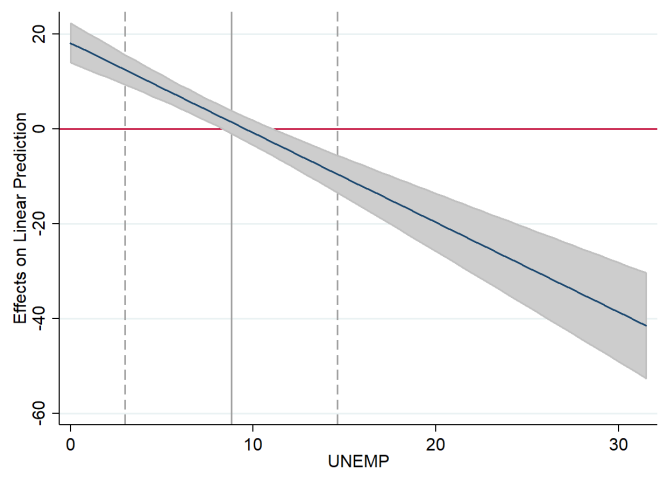

(b) Post-2008 (CRISIS=1)

party (H10). In contrast, estimates for CONSINGOV in ERP models go against expectations (H11), suggesting that far-right parties perform worse when left-wing parties are in power - almost 5 points less. It could be the case that mainstream conservative parties - also in the opposition - capture potential ERP voters by attracting "useful votes". Yet, neither the data nor the literature provides clues to understanding the inverse signs among radical parties.

Taken together, results indicate that supply-side factors are crucial to understanding APE performance, but also make the case for testing it against economic conditions. While it may appear that crises and rising unemployment benefit radical parties as such, a lot can be clarified by disentangling these relationships. This is especially true for the diverging estimates for unemployment rates in models with radical left and right-wing parties - and how these connections behave after 2008. Seemingly, the post-2008 right-wing growth stumbled exactly where joblessness prompted the left.

Because regression data alone cannot sustain deeper insights, I turn to discussing hypotheses regarding the larger picture. To that end, I also reach out to the descriptive analysis from Section 2 and the literature examined in Section 3 . In this way, I analyze new data alongside conflicting accounts on the political economy of radical party vote. 


\section{Discussion}

This work shows that European far-right parties became stronger as the financial crisis of 2008 took place, while the same does not apply for the radical left. Such a pattern is confirmed by additional studies (Brückner and Grüner, 2010; Funke, Schularick, and Trebesch, 2015), leading to the central hypothesis that economic downturns, as a general rule, tend to strengthen right-wing extremism.

This would be the case irrespective of a nation's migrant stock or aggregate perception of ethnic diversity, and the losers of globalization would explain this backlash only partially. This is not to say that globalization shocks bear no relation to populism. Rather, I assume that degrees of exposure to economic globalization do not explain cross-country differences. Indeed, this is consistent with not assuming an aggregate level correlation between ethnic diversity and far-right support - which seems to be the most prudent take, given the diverging evidence 28 .

Arguably, during a crisis, these voters don't necessarily blame minorities. The sole perception of outgroups as competitors for waning resources could suffice to trigger chauvinism. In other words, the primary motive would be less about scapegoating than about wanting to secure the natives' slice of a shrinking pie. This could apply both to blue-collar workers and to upper-class citizens, in a way that the hypothesis is coherent with the heterogeneity of far-right electorates29. It is also in harmony with evidence that, among ERP supporters, xenophobic attitudes and negative perceptions of the economy prevail ${ }^{30}$.

Contrastingly, radical left parties would profit where economic distress involves exceptional conditions. In the present case, these would be severe government budget cuts and unemployment soaring to unusual rates, even for a crisis context. People in these countries also witnessed national and supranational authorities in strenuous negotia-

\footnotetext{
${ }^{28}$ As discussed on page 16

${ }^{29}$ As suggested by Ivarsflaten (2005), Evans (2005), and Zhirkov (2014).

${ }^{30}$ E.g. Lubbers, Gijsberts, and Scheepers (2002), Zhirkov (2014), and Burni (2017).
} 
tions, resulting in unpopular measures with a taste of external meddling. Admittedly, this work's estimates for unemployment in RLP models could be inconsistent, as results do not correspond to supplementary regressions with the inverse hyperbolic sine (IHS) transformation (see page 37 in the Appendix). Yet, the link between unemployment and radical left support is largely agreed upon by the literature (E.g. March and Rommerskirchen, 2015 Bowyer and Vail, 2011; Sperber, 2010), and this work's descriptive analysis displays a clear cleavage on the national level: one that opposes high unemployment, austerity-driven countries with a relevant radical left; and lowunemployment, less fiscally conservative countries with weak or nonexistent RLPs. In sum, despite inconclusive regression results, additional sources indicate that the economic setting of southern Europe has helped to invigorate left-wing populism.

Granted, this general hypothesis is concerned exclusively with the demand side of populism: It proposes that economic conditions help to settle whether populists on the left or on the right have more potential. Whether this potential is fulfilled is a different question, one that demands reaching out to the supply side. In fact, past research emphasizes party leadership, past party success, and electoral systems as central to the performance of populist parties, left and right ${ }^{31}$. Arguably, distinguishing between demand and supply should be critical to understanding the counterfactual cases seen in Section 2. All being said, however, I hope to have made the case that analyses of populist party success should look attentively at economic conditions.

In conclusion, this work shows that 2008 has preceded a rise of extreme right parties, one that took place more intensely in wealthier regions, and regions with lower unemployment rates. In contrast, unemployment is possibly linked to far-left support, although results for the 2002-2011 reveal no evidence of a post-2008 rise in RLP voting. The models suggest that, as a general rule, the extreme right has a window of opportunity during economic crises, especially in regions of higher income, and with relatively low levels of unemployment. Where the outreach of unemployment is unusual, even

\footnotetext{
${ }^{31}$ E.g. Lubbers, Gijsberts, and Scheepers (2002), Golder (2003), Mudde (2007), and March and Rommerskirchen (2015).
} 
for a country in crisis, the stage is set for an exception to the rule, at which right-wing extremism falters and the radical left might have the edge. By distinguishing between the settings where extreme right and radical left parties succeed, the results enable us to better understand the diverging anti-establishment votes. 


\section{References}

Autor, David et al. (2016). Importing Political Polarization? The Electoral Consequences of Rising Trade Exposure. MIT Working Paper. Massachusetts Institute of Technology. URL: http : / / economics . mit . edu/files / 11499 (visited on 06/18/2017).

Bakker, Ryan et al. (2015). "Measuring party positions in Europe The Chapel Hill expert survey trend file, 1999-2010". In: Party Politics 21.1, pp. 143-152.

Bale, Tim and Richard Dunphy (2011). "In from the cold? Left parties and government involvement since 1989". In: Comparative European Politics 9.3, pp. 269-291.

Bartolini, Stefano (2007). The Political Mobilization of the European Left, 1860-1980: The Class Cleavage. Cambridge University Press. 664 pp.

Beck, Nathaniel (2001). "Time-series-cross-section data: What we have learned in the past few years". In: Annual Review of Political Science 4.1, pp. 271-293.

Beck, Thorsten et al. (2001). "New Tools in Comparative Political Economy: The Database of Political Institutions". In: The World Bank Economic Review 15.1, pp. $165-176$.

Becker, Sascha, Thiemo Fetzer, and Dennis Novy (2016). Who Voted for Brexit? A Comprehensive District-Level Analysis. CAGE Online Working Paper Series. Competitive Advantage in the Global Economy (CAGE). URL: http://econpapers. repec.org/paper/cgewacage/305.htm (visited on 07/18/2017).

Beyme, Klaus von, ed. (1988). Right-wing extremism in Western Europe. London ; Totowa, NJ: Cass. 110 pp.

Bowyer, Benjamin T. and Mark I. Vail (2011). "Economic Insecurity, the Social Market Economy, and Support for the German Left". In: West European Politics 34.4, pp. 683-705.

Brückner, Markus and Hans Peter Grüner (2010). Economic growth and the rise of political extremism: theory and evidence. CEPR Discussion Paper 7723. C.E.P.R. Discussion Papers. URL: https://ideas.repec.org/p/cpr/ceprdp/7723.html (visited on 06/06/2016).

Burni, Aline (2017). "Beyond Protest Vote: Western European Extreme Right Voters in Comparative Perspective". In: 75th Annual MPSA conference. Chicago.

Coffé, Hilde, Bruno Heyndels, and Jan Vermeir (2007). "Fertile grounds for extreme right-wing parties: Explaining the Vlaams Blok's electoral success". In: Electoral Studies 26.1, pp. 142-155.

Colantone, Italo and Piero Stanig (2016). Global Competition and Brexit. SSRN Scholarly Paper ID 2870313. Rochester, NY: Social Science Research Network. URL: https://papers.ssrn. com/abstract=2870313 (visited on 06/18/2017). 
Colantone, Italo and Piero Stanig (2017). The Trade Origins of Economic Nationalism: Import Competition and Voting Behavior in Western Europe. SSRN Scholarly Paper ID 2904105. Rochester, NY: Social Science Research Network. URL: https: //papers. ssrn. com/abstract=2904105 (visited on 06/18/2017).

De Weerdt, Yves et al. (2004). Turning Right? Socio-Economic Change and the Receptiveness of European Workers to the Extreme Right. Report on the Survey Analysis and Results. SIREN-project (Socio-Economic Change, Individual Reactions and the Appeal of the Extreme Right).

Dennison, Susi and Dina Pardijs (2016). The world according to Europe's insurgent parties: Putin, migration and people power. London: European Council on Foreign Relations. URL: http : / / www . ecfr . eu/publications/summary/the_world_ according_to_europes_insurgent_parties7055 (visited on 06/18/2017).

Derks, Anton (2006). "Populism and the ambivalence of egalitarianism. How do the underprivileged reconcile a right wing party preference with their socio-economic attitudes?" In: World Political Science Review 2.3, pp. 175-200.

Dippel, Christian, Robert Gold, and Stephan Heblich (2015). Globalization and Its (Dis-)Content: Trade Shocks and Voting Behavior. Working Paper 21812. National Bureau of Economic Research. URL: http : //www . nber . org/papers/w21812 (visited on $04 / 26 / 2016$ ).

Evans, Jocelyn A. J. (2005). "The Dynamics of Social Change in Radical Right-wing Populist Party Support”. In: Comparative European Politics 3.1, pp. 76-101.

Funke, Manuel, Moritz Schularick, and Christoph Trebesch (2015). Politics in the Slump: Polarization and Extremism after Financial Crises, 1870-2014. Discussion Paper 10884. Center for Economic Policy Research.

Germani, Gino, Torcuato Tella, and Octavio Ianni (1977). Populismo y contradicciones de clase en Latinoamérica. Mexico: Era.

Golder, Matt (2003). "Explaining Variation In The Success Of Extreme Right Parties In Western Europe". In: Comparative Political Studies 36.4, pp. 432-466.

Guiso, Luigi, Helios Herrera, and Massimo Morelli (2017). Demand and Supply of Populism. SSRN Scholarly Paper ID 2924731. Rochester, NY: Social Science Research Network. URL: https://papers . ssrn. com/abstract=2924731 (visited on 06/18/2017).

Hudson, K (2012). New european left: a socialism for the twenty-first century? Basingstoke: Palgrave Macmillan.

Husbands, Christopher T. (1991). "The support for the front national: Analyses and findings". In: Ethnic and Racial Studies 14.3, pp. 382-416.

Ivarsflaten, Elisabeth (2005). "The vulnerable populist right parties: No economic realignment fuelling their electoral success". In: European Journal of Political Research 44.3, pp. 465-492. 
Jackman, Robert W. and Karin Volpert (1996). "Conditions Favouring Parties of the Extreme Right in Western Europe". In: British Journal of Political Science 26.4, pp. 501-521.

Jesuit, David K., Piotr R. Paradowski, and Vincent A. Mahler (2009). "Electoral support for extreme right-wing parties: A sub-national analysis of western European elections". In: Electoral Studies 28.2, pp. 279-290.

Kitschelt, Herbert P. (1988). "Left-Libertarian Parties: Explaining Innovation in Competitive Party Systems". In: World Politics 40.2, pp. 194-234.

Knigge, Pia (1998). "The ecological correlates of right-wing extremism in Western Europe". In: European Journal of Political Research 34.2, pp. 249-279.

Lewis-Beck, Michael and Richard Nadeau (2011). "Economic voting theory: Testing new dimensions". In: Electoral Studies 30.2, pp. 288-294.

- (2012). "PIGS or not? Economic voting in Southern Europe". In: Electoral Studies 31.3 , pp. $472-477$.

Lijphart, Arend and Don Aitkin (1994). Electoral Systems and Party Systems: A Study of Twenty-seven Democracies, 1945-1990. Oxford University Press. 209 pp.

Lubbers, Marcel, Mérove Gijsberts, and Peer Scheepers (2002). "Extreme right-wing voting in Western Europe". In: European Journal of Political Research 41.3, pp. 345378.

Mair, Peter (2013). Ruling the Void: The Hollowing of Western Democracy. London: Verso.

March, Luke (2008). Contemporary Far Left Parties in Europe From Marxism to the Mainstream? International Policy Analysis. Berlin: Friedrich Ebert Stiftung.

March, Luke and Cas Mudde (2005). "What's left of the radical left? The European radical left after 1989: Decline and mutation". In: Comparative European Politics 3.1, pp. 23-49.

March, Luke and Charlotte Rommerskirchen (2015). "Out of left field? Explaining the variable electoral success of European radical left parties". In: Party Politics 21.1, pp. $40-53$.

Minkenberg, Michael (2013). "The European radical right and xenophobia in West and East: trends, patterns and challenges in right-wing extremism in Europe." In: Right-wing extremism in Europe. Ed. by R. Melzer and S. Serafin. Berlin: Friederich Ebert Stiftung.

Mudde, Cas (2007). Populist radical right parties in Europe. Cambridge: Cambridge University Press.

- (2010). "The populist radical right: A pathological normalcy". In: West European Politics 33.6, pp. 1167-1186. 
Müller, Jan-Werner (2014). "The party's over". In: London Review of Books, pp. 35-37. URL: http://www.lrb.co.uk/v36/n10/jan-werner-muller/the-partys-over (visited on $07 / 06 / 2016$ ).

- (2016). What Is Populism? Philadelphia: University of Pennsylvania Press. 136 pp.

Mundo, Voz do (2017). Episódio 2 - Philippe Schmitter (pt 2). URL: https: //soundcloud. com/vozdomundo/episodio-2 (visited on 06/18/2017).

Norris, Pippa (2005). Radical Right: Voters and Parties in the Electoral Market. New York, NY: Cambridge University Press. 366 pp.

Panizza, Francisco (2005). "Introduction". In: Populism and the mirror of democracy. Ed. by Francisco Panizza. OCLC: 254213319. London: Verso.

Rodrik, Dani (2017). "Populism and the Economics of Globalization". URL: http: $/ /$ j.mp/2sowhXj (visited on 06/12/2017).

Sperber, Nathan (2010). "Three million Trotskyists? Explaining extreme left voting in France in the 2002 presidential election". In: European Journal of Political Research 49.3, pp. 359-392.

Swank, Duane and Hans-Georg Betz (2003). "Globalization, the welfare state and right-wing populism in Western Europe". In: Socio-Economic Review 1.2, pp. 215245.

Tella, Torcuato (2010). Latin American Politics: A Theoretical Approach. Austin: University of Texas Press. 233 pp.

Wendt, Christopher (2003). "Toward a majoritarian model for Western Europe". In: 99th annual APSA meeting. Philadelphia.

Wooldridge, Jeffrey M. (2010). Econometric Analysis of Cross Section and Panel Data. Cambridge: The MIT Press. 1096 pp.

Zhirkov, Kirill (2014). "Nativist but not alienated A comparative perspective on the radical right vote in Western Europe". In: Party Politics 20.2, pp. 286-296. 


\section{Appendix}

\section{Summary Statistics}

Total (subnational data - NUTS 2 regions)

\begin{tabular}{llllll}
\hline VARIABLES & $\mathrm{N}$ & mean & $\mathrm{sd}$ & $\min$ & $\max$ \\
\hline ERPVOTE1 & 273 & 5.562 & 7.677 & 0 & 47 \\
RLPVOTE1 & 251 & 6.593 & 5.670 & 0 & 26.10 \\
GDP & 273 & 24,182 & 6,598 & 11,800 & 53,700 \\
GROWTH & 273 & 2.560 & 4.119 & -15.56 & 16.83 \\
UNEMP & 264 & 8.808 & 5.809 & 1.200 & 31.50 \\
\hline
\end{tabular}

2002-2008 (CRISIS $=0)$

\begin{tabular}{llllll}
\hline VARIABLES & $\mathrm{N}$ & mean & $\mathrm{sd}$ & $\min$ & $\max$ \\
\hline & & & & & \\
ERPVOTE1 & 209 & 4.534 & 6.154 & 0 & 32.71 \\
RLPVOTE1 & 187 & 6.755 & 5.949 & 0 & 26.10 \\
GDP & 209 & 23,826 & 6,434 & 11,800 & 53,700 \\
GROWTH & 209 & 4.340 & 2.145 & -1.650 & 16.83 \\
UNEMP & 200 & 8.198 & 4.945 & 1.200 & 31.50 \\
\hline
\end{tabular}

Austria

\begin{tabular}{llllll}
\hline VARIABLES & $\mathrm{N}$ & mean & $\mathrm{sd}$ & $\min$ & $\max$ \\
\hline & & & & & \\
ERPVOTE1 & 27 & 18.96 & 10.06 & 6.370 & 47 \\
RLPVOTE1 & 27 & 0 & 0 & 0 & 0 \\
GDP & 27 & 28,052 & 5,921 & 17,800 & 40,300 \\
GROWTH & 27 & 3.656 & 2.492 & -0.620 & 7.230 \\
UNEMP & 27 & 4.363 & 1.669 & 2.400 & 9.700 \\
\hline
\end{tabular}

Denmark

\begin{tabular}{llllll}
\hline VARIABLES & $\mathrm{N}$ & mean & $\mathrm{sd}$ & $\min$ & $\max$ \\
\hline ERPVOTE1 & 5 & 14.13 & 1.876 & 12.42 & 16.74 \\
RLPVOTE1 & 5 & 12.57 & 1.951 & 10.29 & 15.60 \\
GDP & 5 & 28,100 & 5,150 & 21,900 & 36,200 \\
GROWTH & 5 & 4.430 & 0.826 & 3.300 & 5.360 \\
\hline
\end{tabular}

Germany

\begin{tabular}{llllll}
\hline VARIABLES & $\mathrm{N}$ & mean & $\mathrm{sd}$ & $\min$ & $\max$ \\
\hline & & & & & \\
ERPVOTE1 & 38 & 1.720 & 1.133 & 0.690 & 5.430 \\
RLPVOTE1 & 38 & 8.953 & 8.045 & 3.050 & 26.10 \\
GDP & 38 & 25,239 & 6,220 & 17,300 & 47,300 \\
GROWTH & 38 & 4.404 & 1.370 & 1.850 & 8.470 \\
UNEMP & 36 & 10.81 & 4.325 & 5.800 & 21.40 \\
\hline
\end{tabular}

Total (aggregate national data)

\begin{tabular}{|c|c|c|c|c|c|}
\hline VARIABLES & $\mathrm{N}$ & mean & sd & $\min$ & $\max$ \\
\hline ERPVOTE1 & 19 & 9.635 & 6.631 & 0 & 28.24 \\
\hline RLPVOTE1 & 19 & 4.177 & 4.927 & 0 & 16.60 \\
\hline GDP & 19 & 26,200 & 3,581 & 19,200 & 31,100 \\
\hline GROWTH & 19 & 2.253 & 3.765 & -7.463 & 5.802 \\
\hline UNEMP & 19 & 7.447 & 4.441 & 2.100 & 21.40 \\
\hline \multicolumn{6}{|c|}{$2008-2011($ CRISIS $=1)$} \\
\hline VARIABLES & $\mathrm{N}$ & mean & sd & $\min$ & $\max$ \\
\hline ERPVOTE1 & 64 & 8.919 & 10.70 & 0 & 47 \\
\hline RLPVOTE1 & 64 & 6.119 & 4.771 & 0 & 17.04 \\
\hline GDP & 64 & 25,345 & 7,034 & 15,500 & 52,400 \\
\hline GROWTH & 64 & -3.250 & 3.643 & -15.56 & 2.300 \\
\hline UNEMP & 64 & 10.71 & 7.665 & 2.100 & 30.10 \\
\hline \multicolumn{6}{|c|}{ Belgium } \\
\hline VARIABLES & $\mathrm{N}$ & mean & $\mathrm{sd}$ & $\min$ & $\max$ \\
\hline ERPVOTE1 & 33 & 7.907 & 8.194 & 0 & 24.09 \\
\hline RLPVOTE1 & 11 & 1.455 & 0.671 & 0.700 & 3.100 \\
\hline GDP & 33 & 25,982 & 9,647 & 16,700 & 53,700 \\
\hline GROWTH & 33 & 1.385 & 4.366 & -7.470 & 6.130 \\
\hline UNEMP & 33 & 7.918 & 3.906 & 4.100 & 17.60 \\
\hline
\end{tabular}

France

\begin{tabular}{llllll}
\hline VARIABLES & $\mathrm{N}$ & $\operatorname{mean}$ & $\mathrm{sd}$ & $\min$ & $\max$ \\
\hline & & & & & \\
ERPVOTE1 & 26 & 9.412 & 5.112 & 0 & 19.02 \\
RLPVOTE1 & 26 & 4.925 & 4.139 & 0 & 21.94 \\
GDP & 26 & 19,412 & 4,332 & 11,800 & 35,400 \\
GROWTH & 26 & 4.977 & 2.812 & 1.450 & 16.83 \\
UNEMP & 25 & 11.52 & 7.405 & 4.900 & 31.50 \\
\hline
\end{tabular}

Greece

\begin{tabular}{llllll}
\hline VARIABLES & $\mathrm{N}$ & mean & $\mathrm{sd}$ & $\min$ & $\max$ \\
\hline ERPVOTE1 & 39 & 3.027 & 1.681 & 0.650 & 7.530 \\
RLPVOTE1 & 39 & 10.37 & 3.687 & 5.310 & 19.50 \\
GDP & 39 & 19,172 & 3,583 & 14,100 & 29,300 \\
GROWTH & 39 & 0.617 & 4.694 & -8.100 & 10.39 \\
UNEMP & 39 & 9.536 & 1.945 & 5.300 & 15.90 \\
\hline
\end{tabular}


Netherlands

\begin{tabular}{llllll}
\hline VARIABLES & $\mathrm{N}$ & mean & $\mathrm{sd}$ & $\min$ & $\max$ \\
\hline & & & & & \\
ERPVOTE1 & 48 & 5.142 & 6.622 & 0 & 26.79 \\
RLPVOTE1 & 48 & 9.584 & 4.716 & 4.520 & 20.56 \\
GDP & 48 & 27,429 & 5,309 & 19,100 & 40,700 \\
GROWTH & 48 & 1.251 & 5.962 & -15.56 & 13.45 \\
UNEMP & 48 & 3.144 & 0.956 & 1.200 & 5.200 \\
\hline
\end{tabular}

Spain

\begin{tabular}{llllll}
\hline VARIABLES & $\mathrm{N}$ & mean & $\mathrm{sd}$ & $\min$ & $\max$ \\
\hline & & & & & \\
ERPVOTE1 & 57 & 0 & 0 & 0 & 0 \\
RLPVOTE1 & 57 & 4.272 & 2.715 & 0 & 13.42 \\
GDP & 57 & 23,130 & 4,929 & 13,400 & 33,900 \\
GROWTH & 57 & 2.659 & 2.866 & -2.340 & 7.980 \\
UNEMP & 56 & 13.32 & 6.830 & 4.700 & 30.10 \\
\hline
\end{tabular}

Table 2: Summary of All Variables

\begin{tabular}{|c|c|c|}
\hline Variable name & Description & Source \\
\hline ERPVOTE & Extreme Right Party vote share & EED, CHES \\
\hline RLPVOTE & Radical Left Party vote share & EED, CHES \\
\hline UNEMP & $\begin{array}{l}\text { Unemployment rates by NUTS } 2 \text { regions }(\%) \text { - } \\
15 \text { years or over }\end{array}$ & Eurostat \\
\hline GDP & $\begin{array}{l}\text { Gross domestic product (GDP) at } \\
\text { current market prices by NUTS } 2 \text { regions - } \\
\text { Purchasing Power Standard per inhabitant }\end{array}$ & Eurostat \\
\hline GROWTH & $\begin{array}{l}\text { Gross domestic product (GDP) at current market } \\
\text { prices by NUTS } 2 \text { regions - } \\
\text { Annual Growth }\end{array}$ & Eurostat \\
\hline CRISIS & 1 if election after September 2008, 0 otherwise & $\begin{array}{l}\text { Parties and } \\
\text { Elections }\end{array}$ \\
\hline THRESH & $\begin{array}{l}1 \text { if a party must obtain a minimum of } \\
3 \% \text { vote share in order to take at least one } \\
\text { seat in a legislature, } 0 \text { otherwise }\end{array}$ & $\begin{array}{l}\text { Based on } \\
\text { Beck et al. (2001) }\end{array}$ \\
\hline CONSINGOV & $\begin{array}{l}1 \text { if a right-wing government was in } \\
\text { government at election date, } 0 \text { otherwise }\end{array}$ & $\begin{array}{l}\text { Parties and } \\
\text { Elections }\end{array}$ \\
\hline SOCINGOV & $\begin{array}{l}1 \text { if a left-wing government was in } \\
\text { government at election date, } 0 \text { otherwise }\end{array}$ & $\begin{array}{l}\text { Parties and } \\
\text { Elections }\end{array}$ \\
\hline
\end{tabular}


Table 3: Dependent variables are the vote shares for extreme right and radical left parties

\begin{tabular}{|c|c|c|c|c|}
\hline \multirow[t]{2}{*}{ VARIABLES } & \multicolumn{2}{|c|}{ Left } & \multicolumn{2}{|c|}{ Right } \\
\hline & Model 1 & Model 2 & Model 1 & Model 2 \\
\hline GDP & $\begin{array}{l}8.00 \mathrm{e}-05 \\
(5.97 \mathrm{e}-05)\end{array}$ & $\begin{array}{l}0.000114 \\
(7.63 \mathrm{e}-05)\end{array}$ & $\begin{array}{l}0.000239^{* * *} \\
(7.03 \mathrm{e}-05)\end{array}$ & $\begin{array}{l}0.000209 * * * \\
(6.08 \mathrm{e}-05)\end{array}$ \\
\hline UNEMP & $\begin{array}{l}0.373^{* * *} \\
(0.101)\end{array}$ & $\begin{array}{l}0.472^{* * * *} \\
(0.163)\end{array}$ & $\begin{array}{l}-0.308^{* * *} \\
(0.107)\end{array}$ & $\begin{array}{c}-0.220^{* *} \\
(0.0890)\end{array}$ \\
\hline GROWTH & $\begin{array}{l}0.143 \\
(0.0941)\end{array}$ & & $\begin{array}{l}-0.485^{* * *} \\
(0.125)\end{array}$ & \\
\hline CRISIS & & $\begin{array}{l}3.287 \\
(2.918)\end{array}$ & & $\begin{array}{l}14.76^{* * *} \\
(3.398)\end{array}$ \\
\hline CRISIS*GDP & & $\begin{array}{l}-6.93 \mathrm{e}-05 \\
(9.43 \mathrm{e}-05)\end{array}$ & & $\begin{array}{l}0.000141 \\
(8.75 \mathrm{e}-05)\end{array}$ \\
\hline CRISIS*UNEMP & & $\begin{array}{l}-0.218 \\
(0.155)\end{array}$ & & $\begin{array}{l}-1.891^{* * *} \\
(0.232)\end{array}$ \\
\hline THRESH & $\begin{array}{l}-7.564^{* * *} \\
(1.204)\end{array}$ & $\begin{array}{l}-7.505^{* * *} \\
(1.195)\end{array}$ & $\begin{array}{l}-32.36^{* * *} \\
(2.424)\end{array}$ & $\begin{array}{l}-25.09^{* * *} \\
(2.199)\end{array}$ \\
\hline CONSINGOV(SOCINGOV) & $\begin{array}{l}3.412^{* * *} \\
(0.695)\end{array}$ & $\begin{array}{l}2.561^{* * *} \\
(0.650)\end{array}$ & $\begin{array}{l}-4.253^{* * *} \\
(1.271)\end{array}$ & $\begin{array}{l}-4.903^{* * *} \\
(1.016)\end{array}$ \\
\hline Country Dummies & & & & \\
\hline Constant & $\begin{array}{l}3.478^{*} \\
(1.793)\end{array}$ & $\begin{array}{l}2.942 \\
(2.130)\end{array}$ & $\begin{array}{l}-1.294 \\
(2.399)\end{array}$ & $\begin{array}{l}-4.412^{* *} \\
(2.090)\end{array}$ \\
\hline Log pseudolikelihood & -602.301 & -602.118 & -583.511 & -552.661 \\
\hline Pseudo R2 & 0.1551 & 0.1554 & 0.1884 & 0.2313 \\
\hline $\mathrm{N}$ & 242 & 242 & 264 & 264 \\
\hline Non-censored & 210 & 210 & 170 & 170 \\
\hline
\end{tabular}

Tobit regression, columns show coefficients with their standard errors in parentheses, *significant at 10 percent; **at 5 percent; ***at 1 percent. 
Table 4: Estimates - Inverse Hyperbolic Sine transformation on the dependent variables

\begin{tabular}{|c|c|c|c|c|}
\hline \multirow[b]{2}{*}{ VARIABLES } & \multicolumn{2}{|c|}{ Left } & \multicolumn{2}{|c|}{ Right } \\
\hline & Model 1 & Model 2 & Model 1 & Model 2 \\
\hline GDP & $\begin{array}{l}1.49 \mathrm{e}-05^{* *} \\
(7.06 \mathrm{e}-06)\end{array}$ & $\begin{array}{l}1.28 \mathrm{e}-05 \\
(8.26 \mathrm{e}-06)\end{array}$ & $\begin{array}{l}5.35 \mathrm{e}-05^{* * *} \\
(1.23 \mathrm{e}-05)\end{array}$ & $\begin{array}{l}5.14 \mathrm{e}-05^{* * *} \\
(1.25 \mathrm{e}-05)\end{array}$ \\
\hline UNEMP & $\begin{array}{l}0.0302^{*} \\
(0.0160)\end{array}$ & $\begin{array}{l}0.0217 \\
(0.0262)\end{array}$ & $\begin{array}{l}-0.0479 * * \\
(0.0224)\end{array}$ & $\begin{array}{l}-0.0347 \\
(0.0214)\end{array}$ \\
\hline GROWTH & $\begin{array}{l}-0.00327 \\
(0.0148)\end{array}$ & & $\begin{array}{l}-0.0669^{* * *} \\
(0.0224)\end{array}$ & \\
\hline CRISIS & & $\begin{array}{l}0.0872 \\
(0.461)\end{array}$ & & $\begin{array}{l}2.062^{* * *} \\
(0.662)\end{array}$ \\
\hline CRISIS*GDP & & $\begin{array}{l}-1.05 \mathrm{e}-06 \\
(1.38 \mathrm{e}-05)\end{array}$ & & $\begin{array}{l}1.58 \mathrm{e}-05 \\
(1.93 \mathrm{e}-05)\end{array}$ \\
\hline CRISIS*UNEMP & & $\begin{array}{l}0.00860 \\
(0.0263)\end{array}$ & & $\begin{array}{l}-0.269^{* * *} \\
(0.0432)\end{array}$ \\
\hline THRESH & $\begin{array}{l}-1.005^{* * *} \\
(0.189)\end{array}$ & $\begin{array}{l}-0.985^{* * *} \\
(0.186)\end{array}$ & $\begin{array}{l}-6.165^{* * *} \\
(0.332)\end{array}$ & $\begin{array}{l}-5.574^{* * *} \\
(0.342)\end{array}$ \\
\hline CONSINGOV(SOCINGOV) & $\begin{array}{l}0.284^{* *} \\
(0.113)\end{array}$ & $\begin{array}{l}0.297^{* * *} \\
(0.104)\end{array}$ & $\begin{array}{l}-1.353^{* * *} \\
(0.260)\end{array}$ & $\begin{array}{l}-1.499^{* * *} \\
(0.231)\end{array}$ \\
\hline Country Dummies & & & & \\
\hline Constant & $\begin{array}{l}2.135^{* * * *} \\
(0.224)\end{array}$ & $\begin{array}{l}2.183^{* * *} \\
(0.253)\end{array}$ & $\begin{array}{l}0.166 \\
(0.445)\end{array}$ & $\begin{array}{l}-0.286 \\
(0.446)\end{array}$ \\
\hline Log pseudolikelihood & -195.166 & -194.223 & -289.633 & -272.997 \\
\hline Pseudo R2 & 0.4855 & 0.4880 & 0.3510 & 0.3883 \\
\hline $\mathrm{N}$ & 242 & 242 & 264 & 264 \\
\hline Non-censored & 210 & 210 & 170 & 170 \\
\hline
\end{tabular}

Tobit regression, columns show coefficients with their standard errors in parentheses, *significant at 10 percent; **at 5 percent; ***at 1 percent. 
Table 5: Fit Statistics - RLP Model 1

\begin{tabular}{lrlr}
\hline Log-Lik Intercept Only & -712.903 & Log-Lik Full Model & -602.301 \\
D $(230)$ & 1204.603 & LR(10) & 221.204 \\
Prob >LR & 0.000 & & \\
McFadden's R2 & 0.155 & McFadden's Adj R2 & 0.138 \\
ML (Cox-Snell) R2 & 0.599 & Cragg-Uhler(Nagelkerke) R2 & 0.601 \\
McKelvey \& Zavoina's R2 & 0.846 & & \\
Variance of y* & 110.810 & Variance of error & 17.039 \\
AIC & 5.077 & AIC*n & 1228.603 \\
BIC & -57.853 & BIC' & -166.315 \\
BIC used by Stata & 1270.470 & AIC used by Stata & 1228.603 \\
\hline
\end{tabular}

Table 6: Fit Statistics - RLP Model 2

\begin{tabular}{lrlr}
\hline Log-Lik Intercept Only & -712.903 & Log-Lik Full Model & -602.118 \\
$\mathrm{D}(228)$ & 1204.236 & LR(12) & 221.571 \\
Prob >LR & 0.000 & & \\
McFadden's R2 & 0.155 & McFadden's Adj R2 & 0.136 \\
ML (Cox-Snell) R2 & 0.600 & Cragg-Uhler(Nagelkerke) R2 & 0.601 \\
McKelvey \& Zavoina's R2 & 0.849 & & \\
Variance of y* & 112.353 & Variance of error & 16.977 \\
AIC & 5.092 & AIC*n & 1232.236 \\
BIC & -47.242 & BIC' & -155.704 \\
BIC used by Stata & 1281.081 & AIC used by Stata & 1232.236 \\
\hline
\end{tabular}

Table 7: Fit Statistics - ERP Model 1

\begin{tabular}{lrlr}
\hline Log-Lik Intercept Only & -718.981 & Log-Lik Full Model & -583.511 \\
D(252) & 1167.022 & LR(10) & 270.940 \\
Prob >LR & 0.000 & & \\
McFadden's R2 & 0.188 & McFadden's Adj R2 & 0.172 \\
ML (Cox-Snell) R2 & 0.642 & Cragg-Uhler(Nagelkerke) R2 & 0.644 \\
McKelvey \& Zavoina's R2 & 0.896 & & \\
Variance of y* & 377.634 & Variance of error & 39.167 \\
AIC & 4.511 & AIC*n & 1191.022 \\
BIC & -238.117 & BIC' & -215.181 \\
BIC used by Stata & 1233.933 & AIC used by Stata & 1191.022 \\
\hline
\end{tabular}

Table 8: Fit Statistics - ERP Model 2

\begin{tabular}{lrlr}
\hline Log-Lik Intercept Only & -718.981 & Log-Lik Full Model & -552.661 \\
D(250) & 1105.322 & LR(12) & 332.640 \\
Prob >LR & 0.000 & & \\
McFadden's R2 & 0.231 & McFadden's Adj R2 & 0.212 \\
ML (Cox-Snell) R2 & 0.716 & Cragg-Uhler(Nagelkerke) R2 & 0.719 \\
McKelvey \& Zavoina's R2 & 0.935 & & \\
Variance of y* & 438.552 & Variance of error & 28.576 \\
AIC & 4.293 & AIC*n & 1133.322 \\
BIC & -288.665 & BIC' & -265.729 \\
BIC used by Stata & 1183.385 & AIC used by Stata & 1133.322 \\
\hline
\end{tabular}


Table 9: Election Dates and Governing Coalitions

\begin{tabular}{lrlll}
\hline \multicolumn{1}{c}{ Contest } & Date & $\begin{array}{l}\text { Incumbent } \\
\text { First party }\end{array}$ & $\begin{array}{c}\text { Elected } \\
\text { First Party }\end{array}$ & \multicolumn{1}{c}{ In Government } \\
\hline Austria 2002 & $24-11-02$ & ÖVP & ÖVP & ÖVP, FPÖ \\
Austria 2006 & $01-10-06$ & ÖVP & SPÖ & ÖVP, FPÖ \\
Austria 2008 & $28-09-08$ & SPÖ & SPÖ & SPÖ, ÖVP \\
Belgium 2003 & $18-05-03$ & VLD & VLD & VLD, PS, MR, SPA \\
Belgium 2007 & $10-06-07$ & VLD & CD\&V & VLD, PS, MR, SPA* \\
Belgium 2010 & $13-10-10$ & CD\&V & N-VA & CD\&V, MR, PS, VLD, CDH \\
Denmark 2007 & $13-11-07$ & Venstre & Venstre & Venstre, KF \\
France 2002 & $09-06-02$ & UMP & UMP & UMP \\
Germany 2005 & $18-09-05$ & SPD & CDU/CSU & SPD, CDU/CSU \\
Greece 2004 & $07-03-04$ & PASOK & ND & ND \\
Greece 2007 & $16-09-07$ & ND & ND & ND \\
Greece 2009 & $04-10-09$ & ND & PASOK & PASOK \\
Netherlands 2002 & $15-05-02$ & PvdA & CDA & CDA, VVD, D66 \\
Netherlands 2003 & $22-01-03$ & CDA & CDA & CDA, VVD, D66* \\
Netherlands 2006 & $22-11-06$ & CDA & CDA & CDA, VVD, D66 \\
Netherlands 2010 & $09-06-10$ & CDA & VVD & VVD, CDA \\
Spain 2004 & $14-03-04$ & PP & PSOE & PSOE \\
Spain 2008 & $09-03-08$ & PSOE & PSOE & PSOE \\
Spain 2011 & $20-11-11$ & PSOE & PP & PP \\
\hline
\end{tabular}

Sources: Parties and Elections (parties-and-elections.eu). 


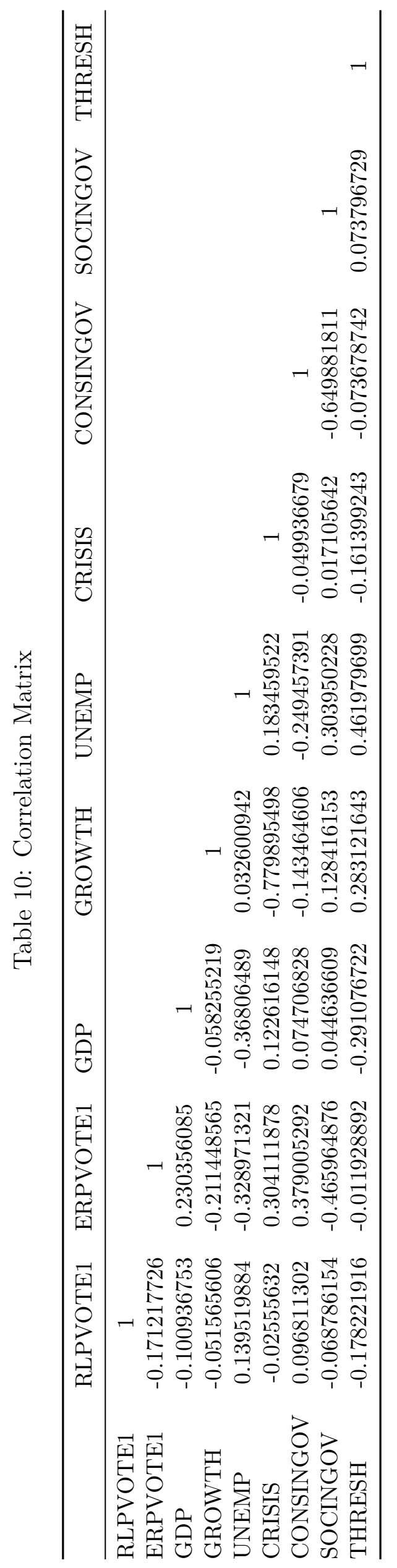




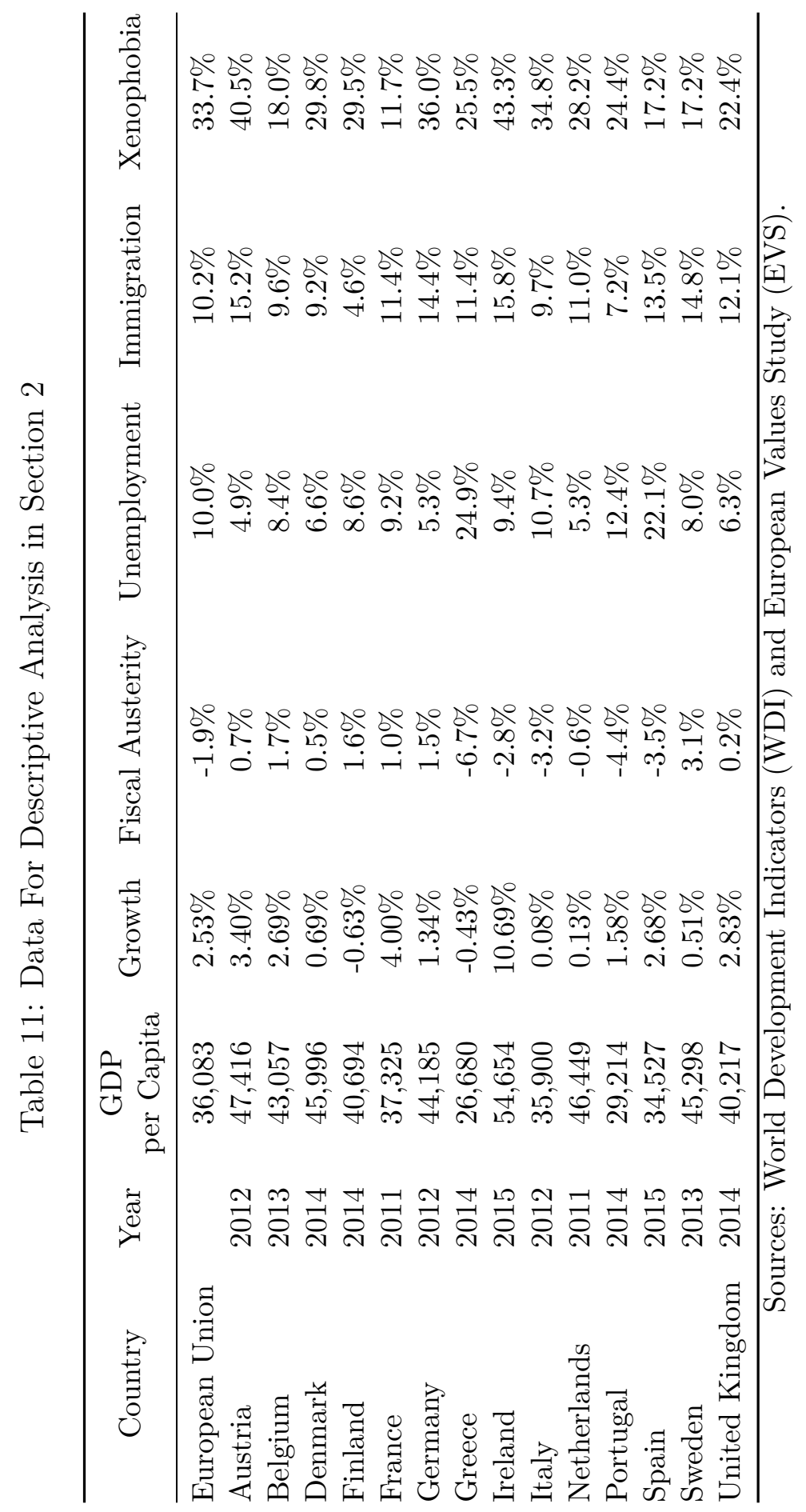




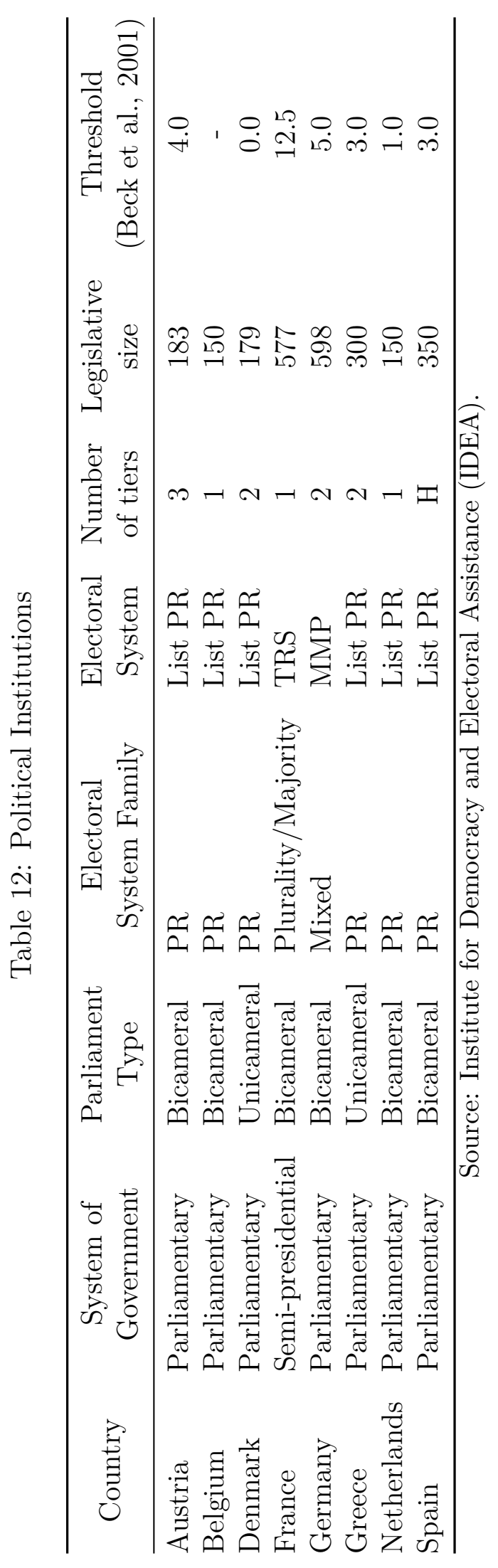




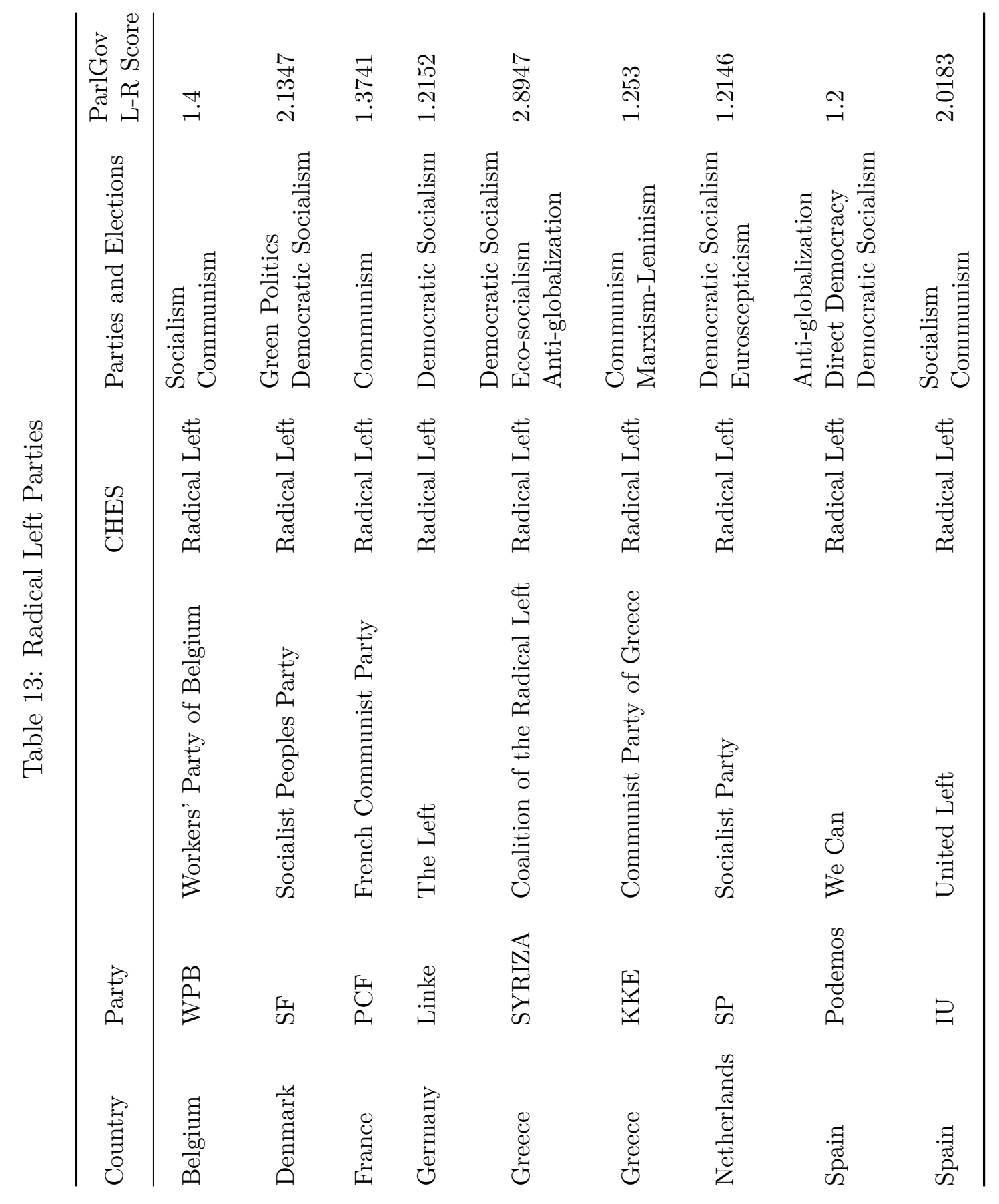




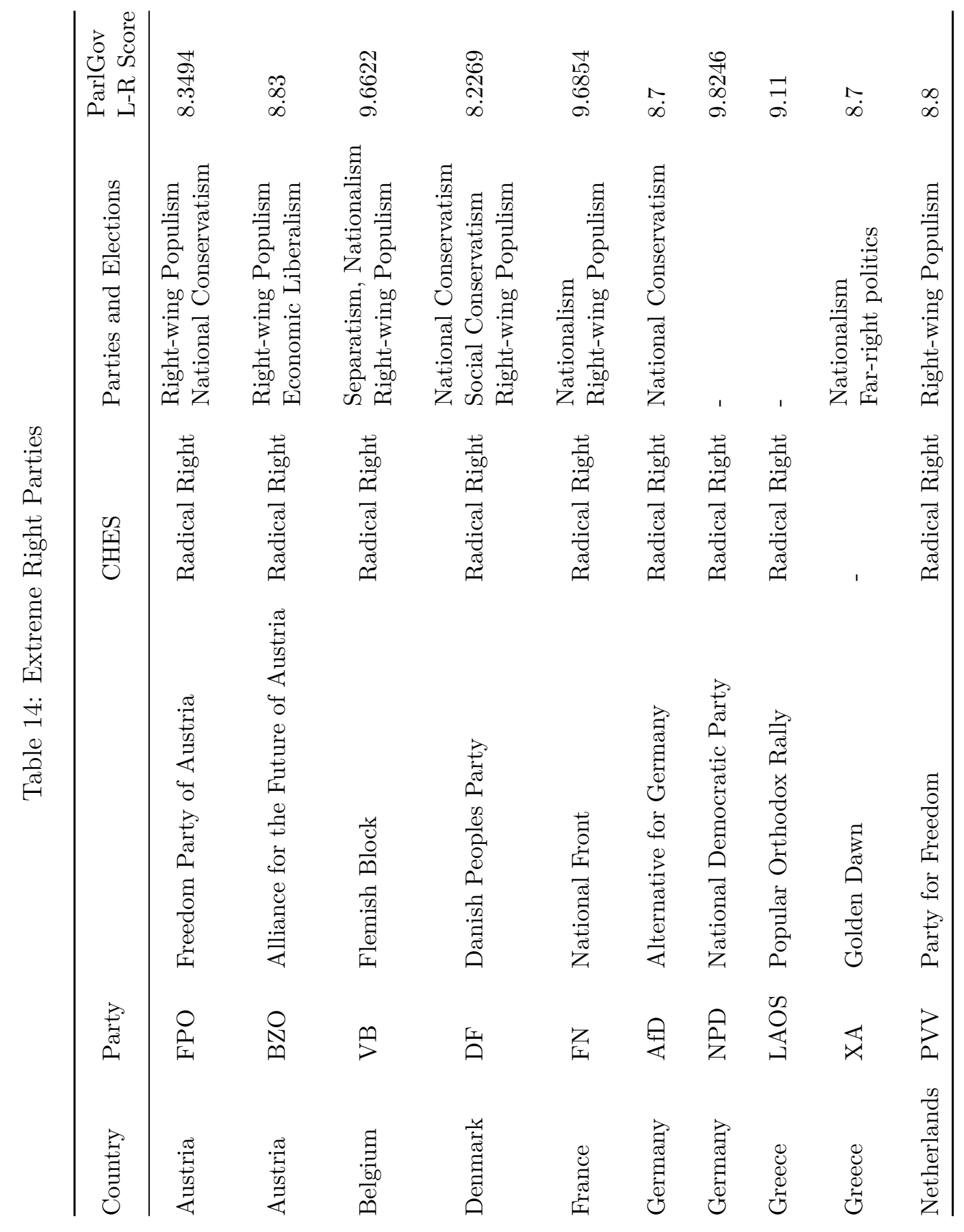




\section{Transcript From Interview With Philippe Schmitter}

The simplest answer is 'geographical': populism on the right comes from the north and populism on the left comes from the south. And that's just too superficial, but that's what it looks like if you look at a map, so to speak.

It seems to me that there's an important hypothesis, and this is a Latin American one. It's due to Gino Germani, I don't know if anybody still reads Gino, he was an Italian-Argentine sociologist, and one of his students, a close friend of mine - he died recently - Torcuato di Tella. Torcuato and I, he was the Argentine ambassador in Rome, so we organized a bunch of conferences between Rome and Florence, on the differences between European populism and Latin American populism. And the central hypothesis from Germani is that the population who are most likely to support populist leaders are people who have what he called status incongruence.

So they have accomplished something, but it hasn't been recognized by the previous aristocracy, or whoever is the oligarchy that's running the country. That's the perfect description of peronistas, for example, and he was studying peronistas, so he...

The inverse are people who had higher status in the past and are declining. So in both cases, you don't have a fit between how people think of themselves in terms of some hierarchy of status, and what has actually happened to them. In one case they (inaudible) don't get recognized and in the other case, they go down. So, the obvious hypothesis is, you get the left in the Latin American cases, and you get the right in Europe, that means, those parts of the population which are threatened by the globalization, de-industrialization, et cetera, these are people who had usually a fairly comfortable middle-class income and then find themselves increasingly, so to speak, relegated to the bottom of the pile.

So that's one way. I'm not saying that's all: obviously, there are a great many factors which differentiate from one country to another. So it's not an accident that populists tend to use nationalism as a major component, and nationalism almost by definition is a bit different in each nation, so the question of the kinds of resentments and the kinds of memories you have about the past, et cetera, tend to be different, so the expression becomes different in different countries, simply because of the attachment to national history.

Nevertheless, I think that that's the beginning of a general hypothesis, that what's happening now is that you have the inverse systems, that's just one hypothesis.

https: //soundcloud.com/vozdomundo/episodio-2\#t=6:45 (accessed 15/Jul/2017) 